\title{
1 Partial-resistance against aphids in wild barley involves phloem and
}

\section{2 mesophyll-based defences}

3

4 Authors:

5 1: Daniel J Leybourne 1,2,3

6 2: Tracy A Valentine ${ }^{3}$

7 3: Jean AH Robertson 4

8 4: Estefania Pérez-Fernández ${ }^{4}$

9 5: Angela M Main 4

10 6: Alison J Karley ${ }^{3}$

11 7: Jorunn IB Bos $1,2^{*}$

Affiliations:

${ }^{1}$ Division of Plant Sciences, School of Life Sciences, Universi ty of Dundee, Dundee, DD2 5DA

${ }^{2}$ Cell and Molecular Sciences, the James Hutton Institute, Invergowrie, Dundee, DD2 5DA,

${ }^{3}$ Ecological Sciences, the James Hutton Institute, Invergowrie, Dundee, DD2 5DA

${ }^{4}$ Environmental and Biochemical Sciences, the James Hutton Institute, Cragiebuckler,

Aberdeen, AB15 8QH

${ }^{*}$ Corresponding author

Date of Submission: $20 / 12 / 2018$

Word Count: 6497

Tables:

1. Table 1: Statistical results of the aphid performance experiments

2. Table 2: Statistical results of significant EPG parameters

3. Table 3: Statistical results of gene expression analysis

4. Table 4: Post-hoc results of gene expression analysis

5. Table 5: Analysis of deviance table for principal component analysis 
6. Table 6: Analysis of deviance table for percentage of essential amino acids

29

30

31

32

33

34

35

36

37

38

39

40

41

42

43

44

45

46

47

48

49

50

1. Fig. 1: Aphid performance results.

2. Fig. 2: Representative aphid feeding patterns.

3. Fig. 3: EPG parameters indicative of epidermal and mesophyll resistance.

4. Fig. 4: EPG parameters indicative of phloem resistance.

5. Fig. 5: Trichome density results.

6. Fig. 6: Gene expression results.

7. Fig. 7: Phloem amino acid composition results. 

mesophyll-based defences

\section{Highlight:}

Partial-resistance against aphids in wild barley is based in the mesophyll and vascular tissue and is potentially associated with higher basal defence gene expression and altered phloem amino acid composition.

\section{Abstract:}

Aphids, including the bird cherry-oat aphid (Rhopalosiphum padi), are significant agricultural pests. Aphid populations are typically controlled using insecticides, but there is increasing demand for more sustainable pest management practices. The wild relative of barley, Hordeum spontaneum 5 (Hsp5) has been described as partially-resistant to R. padi. Partialresistance is proposed to involve higher thionin and lipoxygenase gene expression. However, the underlying mechanistic processes are unknown. In this study we compared Hsp5 with a susceptible cultivar of barley (Concerto) to test the extent to which partial-resistance affects aphid fitness. We used the electrical penetration graph technique to monitor $R$. padifeeding patterns to elucidate the tissue location of partial-resistance factors al ongside molecular and biochemical analyses to identify potential mechanisms. We show that partial-resistance in Hsp5 extends to three aphid species and is mediated by phloem/mesophyll-based factors, leading to a three-fold increase in the time aphids take to establish sustained phloem ingestion. Partial-resistance likely involves elevated expression of defence and phytohormone genes al ongside altered phloem amino acid composition. Further work is required to establish the function of these traits, however this study highlights plant tissues which are important in conferring broad-spectrum partial-resistance against aphids in barley. 


\section{Keywords}

79 Amino Acid Composition, Defence gene expression, Electrical Penetration Graph (EPG),

80 Hordeum spontaneum, Partial-resistance, Rhopalosiphum padi, Sitobion avenae,

81 Utamphorophora humboldti

82 Abbreviations

83 ABA: Abscisic Acid

84 Ala:Alanine

85 Arg: Arginine

86 Asn: Asparagine

87 Asp: Aspartic Acid

88 Concerto: Hordeum vulgare cv. Concerto

89 EPG: Electrical penetration graph

90 ET: Ethylene

91 FTIR: Fourier Transform Infrared

92 Gln:Glutamine

93 Glu: Glutamic Acid

94 Gly: Glycine

95 His: Histidine

96 Hsp5:Hordeum spontaneum 5

97 Ile: Isoleucine

98 JA: Jasmonic Acid

99 Leu: Leucine

100 Lys:Lysine:

101 Met: Methionine

102 Phe: Phenylalanine

$103 r_{m}$ : the intrinsic rate of population increase

104 SA: Salicylic Acid

105 Ser:Serine

106 Thr:Threonine

107 Trp:Tryptophan

108 Tyr:Tyrosine

109 Val:Valine 


\section{Introduction}

114 Barley, Hordeum vulgare, is the fourth most agriculturally important cereal by production quantity (Newton et al., 2011), with 65\% of barley yield being used as feed for livestock, $30 \%$ in malting and distilling processes, and 5\% contributing towards other uses (Newman and Newman, 2006). By 2050 it is estimated that crop yields will need to increase by $60 \%$ in order to meet the demands of global population growth (Alexandratos and Bruinsma, 2012). One way to help achieve this is to reduce yield losses to abiotic and biotic stress factors. Aphids such as the bird cherry-oat aphid, Rhopalosiphum padi, and the English grain aphid, Sitobion avenae, are major pests of cereals. Aphids feed directly from plant phloem using specialised mouthparts known as stylets (Auclair, 1963). Aphids cause direct plant damage by feeding and ingesting phloem sap and act as vectors of economically important plant viruses. Many cereal aphids are vectors for viruses such as Barley Yellow Dwarf Virus (BYDV), which are transmitted into plant tissues during stylet probing (Powell, 2005). Disease resulting from virus infection can cause yield losses of up to $30 \%$ in barley and up to $80 \%$ in wheat (Smith and Sward, 1982; Perry et al., 2000; Murray and Brennan, 2010).

Aphids are primarily controlled through the application of insecticides, with the amount of insecticide used perannum increasing (Jess et al., 2018). However the use of these has led to the emergence of insecticide-resistant aphid populations (Chen et al., 2007; Foster et al., 2014), caused negative impacts on non-target organism (Unal and Jepson, 1991; James et al., 2016), and potentially resulted in an increase in BYDV prevalence (Dewar and Foster, 2017), leading to legislative restrictions on insecticide use and promotion of integrated pest management (Directive, 2009/128/EC). As a consequence, there is a growing requirement for alternative pest management solutions which are more sustainable, and improving crop resistance to aphids is one avenue which could be explored to achieve this.

To date, only partial-resistance against aphids has been reported for cereal crops. Plant resistance traits which are effective against insect pests can be allocated to one of three categories: 1) chemical deterrence of insect settling and feeding; 2 ) physical barriers to insect feeding; and 3) reduction in palatability (Mitchell et al., 2016). Partial-resistance against aphids has been associated with each of these categories (respectively, Gibson and Pickett (1983), Tsumuki et al. (1989) and Greenslade et al. (2016). Inherent molecular defences also 
play a key role in conferring resistance against aphids (Delp et al., 2009; Guan et al., 2015; Escudero-Martinez et al., 2017). Molecular defences shown to be involved in aphid resistance in Hordeum spp. include increased expression of thionin (antimicrobial peptides) genes (Delp et al., 2009; Mehrabi et al., 2014; Escudero-Martinez et al., 2017), increased chitinase and $\beta$ 1,3-glucanase activity (Forslund et al., 2000), and the presence of plant secondary metabolites (Gianoli and Niemeyer, 1998). Plant phythormone signalling pathways, including Abscisic Acid (ABA), Salicylic Acid (SA), Jasmonic Acid (JA) and Ethylene (ET) signalling processes, mediate co-ordinated molecular responses to herbivory via the regulation of defence signalling genes and the biosynthesis of defensive allelochemicals (Smith and Boyko, 2007; Bari and Jones, 2009; Morkunas et al., 2011; Foyer et al., 2016); higher constitutive expression of phytohormone signalling genes can lead to improved resistance against aphids in cereals (Losvik et al., 2017).

Constitutive and induced plant defences are frequently lost during plant breeding and domestication (Moreira et al., 2018). However, wild relatives of modern crops possess traits which confer improved resistance against herbivorous pests (Dempewolf et al., 2014). Screening crop wild relatives for (partial-)resistance against aphids provides an opportunity to identify potentially beneficial traits (Zhang et al., 2017) which can be introduced into agricultural cultivars to improve resistance (Xu et al., 2015; Li et al., 2018). Screening of wild relatives in wheat (Xu et al., 2015; Aradottir et al., 2017), barley (Nieto-Lopez and Blake, 1994; Åhman et al., 2000) and maize (Maag et al., 2015) has resulted in successful identification of partial-resistance traits in wild relatives of these species (Tsumuki et al., 1989; Barria et al., 1992; Gianoli and Niemeyer, 1998; Ahmad et al., 2011; Greenslade et al., 2016; Chandrasekhar et al., 2018; Li et al., 2018).

Partial-resistance against $R$. padi was identified in the barley wild relative H. spontaneum 5 (Hsp5) (Åhman et al., 2000; Delp et al., 2009). Although Hsp5 features higher tissue concentrations of indole alkaloid gramine, a plant defensive compound, the presence of gramine did not correlate with increased partial-resistance (Åhman et al., 2000). Instead, partial-resistance in $\mathrm{Hsp} 5$ is thought to involve increased expression of plant defence genes (Delp et al., 2009; Mehrabi et al., 2014), including higher constitutive expression of thionin genes (Delp et al., 2009) and higher expression of a proteinase inhibitor (Mehrabi et al., 2014). 
partial-resistance in Hsp5 (Delp et al., 2009), although the underlying mechanism(s) of resistance and the tissue location of these resistance factors remains to be elucidated.

The primary aim of this study was to characterise the plant traits and mechanisms contributing to partial-resistance in $\mathrm{Hsp} 5$ by comparison with a susceptible commercial barley cultivar, Concerto, and explore whether this partial-resistance is effective against several aphid species, including two agricultural pests ( $R$. padi and Sitobion avenae) and an invasive species (Utamphorophora humboldti). The factors contributing towards partial-resistance in Hsp5, and their tissue location, were elucidated using the electrical penetration graph (EPG) technique to monitor $R$. padi feeding processes. Subsequently, we assessed differences between the two barley species in leaf surface architecture, defence gene expression, and phloem amino acid composition to gain insight into the potential mechanisms underlying partial resistance in Hsp5.

\section{Materials and methods}

\section{Plant growth and insect rearing conditions}

Hordeum vulgare Linnaeus cv. Concerto (Concerto) and H. spontaneum 5 Linnaeus (Hsp5) seeds were surface-sterilised by washing in $2 \%(v / v)$ hypochlorite and rinsing with $d . \mathrm{H}_{2} \mathrm{O}$. Seeds were kept moist in the dark: $\mathrm{Hsp} 5$ seeds were incubated at $4^{\circ} \mathrm{C}$ for 14 days and Concerto seeds were kept at room temperature for $48 \mathrm{~h}$. Germinated seedlings were planted into a bulrush compost mix (Bulrush, Northern Ireland) and grown under glasshouse conditions with a $16: 8 \mathrm{~h}$ day:night length and a $20: 15^{\circ} \mathrm{C}$ day:night temperature. Plants were grown until the first true leaf stage (1.1-1.2 on the Zadoks et al. (1974) growth staging key).

Asexual laboratory cultures of the bird cherry-oat aphid, Rhopalosiphum padi (Linnaeus) (genotype B; Leybourne et al. (2018)), the English grain aphid, Sitobion avenae Fabricius and the American grass leaf aphid, Utamphorophora humboldti Essig were established from individual apterous adults collected from Dundee, UK. Molecular barcoding of the cytochrome oxidase subunit I gene (Folmer et al., 1994) was used to confirm identity of aphid species. Aphid cultures were reared on one week old barley seedlings (cv. Optic) contained in ventilated cups at $20^{\circ} \mathrm{C}$ and $16: 8 \mathrm{~h}(\mathrm{~L}: \mathrm{D})$. 
The performance of all aphid species was assessed in glasshouse conditions (described above) on Hsp5 and Concerto $(n=12)$ in a randomised block design (each block contained one replicate of each treatment combination). Plants were infested with a single apterous aphid which was allowed to reproduce overnight, then a total of three nymphs were retained on each plant. Mean nymph mass and number of surviving nymphs were recorded at $72 \mathrm{~h}$ and $168 \mathrm{~h}$, after which a random single nymph was returned to the plant; for this nymph, data were collected on the length of the pre-reproductive period (d) and the intrinsic rate of population increase $\left(r_{m}\right)$. Aphids were caged onto the first fully expanded true leaf using Perspex clip-cages of $25 \mathrm{~mm}$ internal diameter (MacGillivray and Anderson, 1957). Nymph mass gain was calculated as the change in mass between 168 and $72 \mathrm{~h}$ and aphid $\mathrm{r}_{\mathrm{m}}$ was calculated using the equation of Wyatt and White (1977): $r m=0.74 \frac{\ln (F d)}{d}$, where $\mathrm{d}$ is the time period between birth and production of first progeny, and $\mathrm{Fd}$ is the total progeny produced over a time period equal to d.

\section{Electrical penetration graph (EPG) monitoring of aphid feeding}

The DC-EPG technique (Tjallingii, 1978; Tjallingii, 1988; Tjallingii, 1991; Tjallingii, 2001) was employed to monitor the probing and feeding behaviour of apterous $R$. padi over a 6 h period using a Giga-4 DC-EPG device (EPG Systems, The Netherlands) on plants at the true-leaf stage. A plant probe (copper rod approximately $50 \mathrm{~mm}$ long $\times 5 \mathrm{~mm}$ diameter), was soldered to electrical wire extending from the plant voltage output of the Giga-4 device and inserted into the plant soil. An aphid probe was made by soldering a piece of copper wire $(30 \mathrm{~mm}$ long $\mathrm{x} 2$ $\mathrm{mm}$ diameter) to a brass pin (tip diameter $2 \mathrm{~mm}$ ). Approximately $30 \mathrm{~mm}$ of gold wire ( $20 \mu \mathrm{m}$ diameter; EPG Systems, The Netherlands) was adhered to the copper end of the aphid probe using water-based silver glue (EPG Systems, The Netherlands) and aphids were connected by adhering the free end of the gold wire onto the aphid dorsum using the same water-based adhesive. Wired aphids were connected to the Giga-4 device by placing the end of the brass pin into the EPG probes with a $1 \mathrm{G} \Omega$ input resistance and a 50x gain (Tjallingii, 1988). The order in which R. padi-plant combinations were tested and allocated to an EPG probe was randomised. Data were acquired using Stylet+D software (EPG Systems, The Netherlands). A 
total of 18 and 16 successful recordings were made for aphids feeding on Concerto and Hsp5, respectively. All EPG recordings were obtained within a grounded Faraday cage.

EPG waveforms were annotated using Stylet+A software (EPG Systems, The Netherlands). Waveforms were annotated by assigning waveforms to $\mathrm{np}$ (non-probing), C (stylet penetration/pathway), pd (intercellular punctures), E1 (saliva secretion into phloem), E2 (saliva secretion and passive phloem ingestion), $F$ (penetration difficulty) or G (xylem ingestion) phases (Tjallingii, 1988; Alvarez et al., 2006). No E1e (extracellular saliva secretion) phases were detected. Annotated waveforms were converted into time-series data using the excel macro developed by Dr Schliephake (Julius Kühn-Institut, Germany).

\section{Determination of non-glandular trichome density}

Non-glandular trichome densities of Hsp5 and Concerto $(n=9)$ were determined using polarised light microscopy following a procedure adapted from Pomeranz et al. (2013). Briefly, the first true leaf was excised from plant stems and treated to two incubation ste ps to clear the leaf epidermis. Firstly, leaf area was measured and leaves were soaked in $96 \%$ Ethanol (Sigma-Aldrich, UK) for 48h before being treated with $1.25 \mathrm{M} \mathrm{NaOH}$ :EtOh (1:1, v:v) at $70^{\circ} \mathrm{C}$ for $2 \mathrm{~h}$. Leaves were stored in $50 \%$ glycerol prior to trichome visualisation; if $\mathrm{NaOH}: \mathrm{EtOH}$ treatment did not clear the leaf epidermis leaves were further treated with $80 \%$ lactic acid for $6 \mathrm{~h}$. To analyse trichome density samples were placed adaxial side up on microscope slides (75 x $25 \mathrm{~mm}$; Corning, UK). A polarising light microscope was created using two $50 \mathrm{~mm}^{2}$ polarising filters (Sigma-Aldrich, UK), one placed below the stage of a stereo-microscope but above the light source and the second attached below the objective lens. Non-glandular trichomes appeared illuminated under the polarised microscope setup and the number of trichomes per unit area were counted. To allow correlation of trichome density with aphid performance, an additional R. padi performance experiment (as described above) was carried out on these plants prior to trichome density analysis.

\section{Epicuticular wax analysis}

A Fourier Transform Infrared (FTIR) spectrometer (Bruker Vertex 70 FTIR spectrometer, Bruker, Ettlingen, Germany), incorporating a Diamond Attenuated Total Reflection (DATR) sampling accessory, was used to identify the functional groups present in chemical extracts from the surfaces of Hsp5 and Concerto leaves. Briefly, the waxes from upper and lowerleaf 
surfaces of the first true leaf $(n=4)$ were extracted with dichloromethane (DCM) by running approximately 1-2 $\mathrm{ml}$ of DCM along the leaf surface directly onto the diamond window of the ATR sampling accessory; after evaporation of the DCM, FTIR spectra were recorded of the films deposited on the DATR. Signal-to-noise ratio was enhanced by taking 200 scans for each sample and averaging to obtain a single spectrum. The spectral range scanned was $4000 \mathrm{~cm}^{-}$ ${ }^{1}$ to $400 \mathrm{~cm}^{-1}$ and a background reading was taken before each sample was analysed.

\section{Analysis of phloem amino acid composition}

Hsp5 and Concerto plants were grown under glasshouse conditions (as described above) in a temporally-split randomised block design: three temporal blocks, one initial temporal block comprising two replicate sub-blocks, and two further temporal blocks each comprising four replicate sub-blocks. Each sub-block contained a single replicate of every treatment combination. Plants at the first true-leaf stage were infested with eitherten apterous $R$. padi adults caged onto the plants with microperforated bags (Polybags, UK) or were aphid-free bagged controls. Samples were collected at 0 and $24 \mathrm{~h}$ post-aphid infestation. Phloem sap was collected using the method of King and Zeevaart (1974); leaves $(n=10)$ were excised from the stem, placed in a dish containing 1 mM EDTA (Sigma-Aldrich, UK) solution and immediately re-cut. The cut surface of the leaf was placed into $200 \mu \mathrm{l}$ of filter-sterilised 1 mM EDTA solution ( $\mathrm{pH} 7.5$ with $\mathrm{NaOH}$ ) in a $2 \mathrm{~mL}$ Eppendorf ${ }^{\mathrm{TM}}$ microcentrifuge tube and incubated for $1.5 \mathrm{~h}$ at room temperature in a darkened exudation chamber (a polystyrene box containing a dish of $6 \mathrm{M} \mathrm{K}_{2} \mathrm{HPO}_{4}$ (Sigma-Aldrich, UK), and moistened paper towels to maximise humidity and decrease leaf transpiration). After incubation, leaves were removed and the samples of EDTA solution containing exuded phloem sap were stored at $-80^{\circ} \mathrm{C}$ until analysis.

Reverse-phase HPLC was used to separate phloem amino acids Asp, Glu, Asn, His, Ser, Gln, Arg, Gly, Thr, Tyr, Ala, Trp, Met, Val, Phe, Ile, Leu and Lys using an Agilent HP1100 series autosampling LC system equipped with a ZORBAX ${ }^{\mathrm{TM}}$ Eclipse AAA column and fluorescence detector. Amino acids were derivatised using o-phthaldialdehyde (Sigma-Aldrich, UK) following the method developed by Jones et al. (1981); all protein amino acids except proline and cysteine could be detected by this method, with a detection limit of approximately 0.5 pmol. Samples were processed in their experimental blocks along with blanks (1 mM EDTA solution that was not exposed to an excised leaf) as controls. Amino acids were identified and 
quantified by comparison with known concentrations of amino acid standards (AA-S-18 (Sigma, UK), supplemented with Asp, Glu and Trp).

\section{qPCR analysis of plant defence genes}

Five sub-blocks over the three temporal blocks (one from the first block and two from each subsequent temporal block) were chosen at random from the phloem exudation experiment described above and leaf tissue was sampled for gene expression analysis. Approximately $25 \mathrm{~mm}$ length of leaf tissue was cut from the true leaf and flash-frozen in liquid nitrogen immediately prior to the excision of the leaf for phloem exudation. Plant material was stored at $-80^{\circ} \mathrm{C}$ until RNA extraction.

For RNA extraction leaf samples were ground to a fine powder under liquid nitrogen using a mortar and pestle and total RNA was extracted with the Norgen Plant/Fungi RNA Extraction Kit (Sigma-Aldrich, UK) following the manufacturer's protocol with additional DNAse I treatment (Qiagen, UK); RNA quality and quantity was assessed with a NanoDrop ${ }^{\circledR}$ ND-1000 Spectrophotometer (ThermoFischer, UK). cDNA synthesis was carried out with approximately 1000 ng RNA using the SuperScript ${ }^{\circledast}$ III cDNA synthesis kit (Sigma-Aldrich, UK), following the manufacturer's protocol. qPCR primers were designed using the Roche Universal Probe Library Assay Design Centre. Reference gene primers were described by Hua et al. (2015). All primer sequences are shown in Supplementary Table 1 and were supplied by Sigma-Aldrich, UK. Primers were validated for PCR efficiency prior to use, and reference gene primers were tested for stability across all treatments following the geNorm procedure (Vandesompele et al., 2002). Gene expression analysis used $\mathrm{SYBR}^{\circledR}$ Green chemistry with GoTaq ${ }^{\circledR}$ qPCR Master Mix (Promega, UK) on a StepOne ${ }^{\mathrm{TM}}$ Real-Time PCR Machine (Applied Biosystems, UK). Reactions were carried out in $12.5 \mu$ reactions with a final concentration of $1 x$ GoTaq $^{\circledR}$ qPCR Master Mix, $1 \mu \mathrm{M}$ of each primer, $1.4 \mathrm{mM} \mathrm{MgCl}$, $2.4 \mu \mathrm{M}$ CXR reference dye and a cDNA quantity of approx. $12.5 \mathrm{ng}$ (assuming 1:1 RNA:cDNA conversion). The qPCR conditions were as follows: $95^{\circ} \mathrm{C}$ for 15 mins followed by 40 cycles of denaturing for $15 \mathrm{~s}$ at $95^{\circ} \mathrm{C}$, annealing for $30 \mathrm{~s}$ at $60^{\circ} \mathrm{C}$, and $30 \mathrm{~s}$ at $72^{\circ} \mathrm{C}$ for DNA extension. Fluorescence was recorded the end of each annealing cycle and a melting curve was incorporated into the end of the qPCR programme. Data were normalised to the mean expression of two reference genes, HVCYP (AK253120.1) and

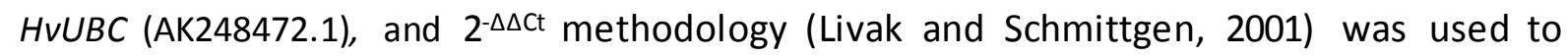
determine differential expression, with Concerto at Oh aphid infestation used as the 
experimental control treatment. Expression levels at $24 \mathrm{~h}$ were further normalised to uninfested control plants. Samples were processed in experimental blocks with three technical replicates at the PCR level.

\section{Statistical analysis}

All statistical analyses were carried out using R Studio v.1.0.143 running R v.3.4.3 (R Core Team, 2014) using packages: car v.2.1-4 (Fox and Weisberg, 2011), coxme v.2.2-7 (Therneau, 2018), dunn.test v.1.3.5 (Dinno, 2017), ggplot2 v.2.2.1 (Wickham, 2009), ggpubr v. 0.1.2 (Kassambara, 2017), ggfortify v.0.4.5 (Tang et al., 2016), lawstat v.3.2 (Hui et al., 2008), Ime4 v.1.1-13 (Bates et al., 2015), ImerTest v.2.0-33 (Kuznetsova etal., 2017), Ismeans v.2.2762 (Lenth, 2016), survival v.2.41-3 (Therneau and Grambsch, 2000), survminer v.0.4.2 (Kassambara and Kosinski, 2017), vegan v.2.5-3 (Oksanen et al., 2013).

Aphid juvenile mass gain and adult $r_{m}$, were modelled using linear mixed effects models with experimental block incorporated as a random factor. ANOVA with type III Satterthwaite approximation for degrees of freedom was used to analyse the final models with calculation of Least Squares Means used for post-hoc testing. A Cox proportional hazards regression model was used for nymph survival analysis (Therneau and Grambsch, 2000; Therneau, 2018), incorporating experimental block as a random factor; a $\chi^{2}$ test was used on the final model. A log-rank test with Benjamini-Hochberg correction was used to carry out pairwise comparisons between aphid-plant combinations. Aphid feeding behaviour was assessed globally by fitting a permutated MANOVA to the dataset. Response variables with normal data distribution were analysed by either ANOVA orgeneral linear models, while non-normally distributed data were analysed with Kruskal-Wallis tests.

Levene's test (Hui et al., 2008) was used to analyse differences in trichome density; a Kendall's rank correlation tau was then used to test for correlations between trichome density and $R$. padi performance. Differences in leaf surface chemistry were analysed using a Welch two sample $t$-test by comparing the total number of identified functional groups in the two plant species.

Phloem amino acid concentrations $(\mathrm{pmol} / \mu \mathrm{l})$ were expressed as relative amino acid composition by converting into mole $\%$ of total amino acid content and subjected to principal component analysis with a correlation matrix. Three principal components explained $69 \%$ of 
observed variation and were analysed by fitting a linear mixed effects model incorporating aphid treatment, plant, time-point, plant $\mathrm{x}$ time-point interaction, and leaf subsampling for RNA (to test effect on amino acid composition) as explanatory variables with temporal block, randomised block and HPLC batch as random factors. Final models were analysed with a $\chi^{2}$

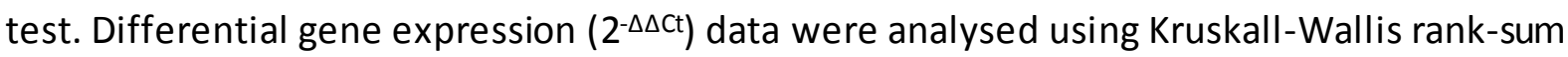
tests, with subsequent Dunn's test post-hoc analysis of the plant $\mathrm{x}$ infestation interaction.

\section{Results}

\section{A wild relative of barley exhibits partial-resistance against multiple aphid species}

Aphid performance experiments were undertaken to assess whether partial-resistance in Hsp5 against $R$. padi (Delp etal., 2009; Leybourne et al., 2018) extends to other aphid species. We assessed the fitness of R. padi, S. avenae, and U. humboldti on Hsp5 in comparison with a commercial barley cultivar (Concerto) and found evidence for partial-resistance against all three aphid species. Specifically, nymph survival was significantly lower on $\mathrm{Hsp} 5\left(\chi^{2}{ }_{1}=10.65\right.$; $p=0.001 ;$ Fig. 1A; Table 1); pairwise comparison showed that nymph survival was reduced on Hsp5 for U. humboldti $(p=<0.001)$, but not for R. padi $(p=0.057)$ or S. avenae $(p=0.973)$. Furthermore, nymph mass gain $\left(F_{56,1}=9.14, p=0.003\right.$; Fig. $1 B$; Table 1$)$ and the rate of population increase $\left(r_{m}\right)\left(F_{54,1}=27.43, p=<0.001\right.$; Fig. 1C; Table 1$)$ were reduced for all aphid species when feeding from Hsp5. Differences were also detected between aphid speci es, with R. padi exhibiting the highest $r_{m}\left(F_{54,2}=99.10, p=<0.001 ; F i g .1 B ;\right.$ Table 1$)$ and S. avenae the largest mass gain ( $F_{56,2}=49.82, p=<0.001$; Fig. $1 C$; Table 1 ). On average $U$. humboldti was the least fit species (Fig. 1A-C).

\section{Partial-resistance against $R$. padi involves mesophyll and phloem resistance factors}

To elucidate the potential underlying partial-resistance mechanism(s) against aphids in Hsp5 R. padi feeding behaviour was monitored using the EPG technique. Overall, the feeding behaviour of $R$. padi differed significantly when feeding from $\mathrm{Hsp} 5$ compared with Concerto $\left(F_{1,33}=2.61 ; p=0.022 ;\right.$ Fig. $2 ;$ Table 2). Aphids showed significant differences in feeding behaviour at the leaf epidermis and within mesophyll tissue (Fig. 3; Table 2). We observed an approximate three-fold decrease in the time to the first epidermal probe when feeding on $\operatorname{Hsp5}\left(F_{1,33}=7.99 ; p=0.008\right)$, alongside a shorter duration of the first probe $\left(F_{1,33}=6.94 ; p=\right.$ $0.013)$ and an increased time to the first sieve element puncture $\left(F_{1,33}=6.33 ; p=0.017\right)$. In 
addition, aphids feeding on Hsp5 showed a two-fold delay in initiating passive phloem ingestion $\left(\chi^{2} 1,33=4.29 ; p=0.038\right)$ and the number of intracellular punctures observed during the first aphid probe of plant tissue was lower, with an average of ten intracellular probes, compared with 24 on Concerto ( $F_{1,33}=3.95 ; p=0.047$; Table 2$)$.

Feeding patterns within the vascular tissue also differed (Fig. 4; Table 2). Specifically, aphids feeding on Hsp5 showed delayed initiation of sustained phloem ingestion (ingestion for $>10$ mins) after the first sieve element puncture $\left(\chi^{2}{ }_{1,33}=4.29 ; p=0.038\right)$. The total length of time aphids spent in the sustained feeding phase was also $2.5 x$ shorter $\left(\chi^{2} 1,33=7.49 ; p=0.006\right)$, and the ratio of time aphids spent ingesting phloem relative to the length of time probing plant tissue (ingestion:pathway ratio) was four-fold lower $\left(\chi^{2} 1,33=7.43 ; p=0.006\right.$ ). Furthermore, aphids feeding on Hsp5 spent three times longer ingesting xylem $\left(\chi^{2}{ }_{1,33}=5.28\right.$; $p=0.022$ ). Table 2 reports additional feeding parameters which highlight further mesophyll and vascular-mediated resistance against $R$. padi in Hsp5.

\section{Leaf surface architecture differs between susceptible and partially-resistant plants.}

The leaf surface represents a key interface between plants and insects, with many factors reported to modulate plant-insect interactions, including leaf trichomes and epicuticular waxes (Agrawal et al., 2009; Glas et al., 2012; Karley et al., 2016). Leaf trichome counts revealed Hsp5 had a significantly higher abundance of non-glandular leaf trichomes $\left(\mathrm{F}_{1,18}=\right.$ 6.24; $p=0.022 ;$ Fig. 5). Non-glandular trichome abundance showed a negative correlation with $R$. padifecundity ( $\mathrm{Z}=-3.60 ; \mathrm{p}=<0.001 ; \mathrm{T}=-0.56$; Supplementary Fig. $1 \mathrm{~A})$ but there was no relation with nymph mass gain $(Z=-0.29 ; p=0.770 ; T=-0.04$; Supplementary Fig. $1 B)$. In addition, we found differences in the epicuticular wax composition between the two plants. The complexity of the epicuticular wax differed in that aliphatic hydrocarbons were detected in surface extracts of Hsp5 leaves, two Hsp5 replicates also contained weak ester bands (Supplementary Table 3). In Concerto the chemical mixture contained a more consistent mixture of aliphatic hydrocarbons and more pronounced ester bands, alongside a more complex, but variable, mixture of chemical groups, including carboxylates and amides $(t=-$ 4.89; $d f=6 ; p=0.002)$. Overall, the results were consistent within Hsp5 but more variable in Concerto (Supplementary Table 3). However, the detection of some Nitrogen-containing functional groups in Concerto leaf extracts could be a result of extracting some components 
within the upper tissue layers, this potentially highlights differences in the thickness of the wax between $\mathrm{Hsp} 5$ and Concerto.

\section{Basal expression levels of several plant defence genes are elevated in Hsp5}

To investigate the level of defence gene expression in Concerto versus Hsp5 we selected marker genes for defensive thionins (HvTHIO1, HvTHIO2, Hv6THIO) alongside JA (HvLOXA, HvLOX2 and HvJAZ), SA (HvNPR1), ET (HvERF), and ABA (HvA1) signalling pathways. We assessed expression of marker genes in both plant types constitutively and in response to $24 \mathrm{~h}$ of aphid infestation. We observed 10-(HvTHIO1), 13-(HvTHIO) and 7-fold (HvBTHIO) higher expression of the three thionin genes in Hsp5 (Fig 6; Table 3). Thionin gene expression levels remained higher in Hsp5 24h after aphid infestation but were not differentially regulated in either plant in response to aphid infestation (Fig 6; Table 3). In addition, HvLOXA, HvLOX2, HVA1, and HVERF1, were more highly expressed in Hsp5, with 3.5-, 6-, 10- and 14-fold higher expression levels, respectively (Fig 6; Table 3).

No genes were differentially expressed in response to aphid infestation. However, several of the phytohormone signalling genes were differentially expressed in response to the plant $x$ aphid infestation interaction; namely HVLOXA, HVLOX2, HVNPR1, and HVERF1 (Table 3). HvLOXA was significantly down-regulated in $\mathrm{Hsp} 5$ after 24h aphid infestation to levels similar to those observed in Concerto (Fig. 6; Table 4). For HvLOX2, HVNPR1, and HvERF, expression levels were higher in Hsp5 after 24h of aphid infestation compared with levels in Concerto (Fig. 6; Table 4). HvJAZ was not differentially regulated in response to any treatment factor.

Phloem amino acid composition in Hsp5 is characterised by a reduction in the proportion of essential amino acids and an increased abundance of asparagine

To investigate phloem factors contributing to partial-resistance against aphids (Fig. 4; Table

2) we analysed the amino acid composition and the proportion of essential and non-essential amino acids in phloem exudates (Fig. 7). Principal component analysis of amino acid composition (mol\% of Asp, Glu, Asn, His, Ser, Gln, Arg, Gly, Thr, Tyr, Ala, Trp, Met, Val, Phe, Ile, Leu, and Lys) of phloem exudates revealed that three principal components explained $69 \%$ of the observed variation in overall amino acid composition, with all three principle components showing a degree of separation between the two plant types (Table 5). Furthermore, $>50 \%$ of the variation was explained by the first two principal components (Fig. 

differences in the relative amounts of Asn and His vs. most other essential amino acids (Fig. 7C). The total percentage of essential amino acids (Arg, His, Ile, Leu, Lys, Met, Phe, Thr, Trp, Val; described in Morris (1991)) was higher in Concerto compared with Hsp5 (18.97\% vs 11.45\%; $\chi^{2}{ }_{1}=25.43 ; p=<0.001 ;$ Fig. 7D; Table 6).

The difference in composition of non-essential amino acids was most pronounced between the two plant types, with a higherproportion of Asn and lowerproportions of Glu and Gly in Hsp5 (42.75\%, 7.34\% and 12.69\%, respectively) compared with Concerto (7.55\%, $15.18 \%$ and $22.43 \%$, respectively) (Fig 7A-B). Amino acid composition and percentage of essential amino acids changed over the $24 \mathrm{~h}$ of the experiment, but not in response to aphid treatment (Table 5; Table 6). Harvesting of leaf material for qPCR analysis had no effect on the phloem amino acid composition (Table 5; Table 6).

\section{Discussion}

In this study we provide evidence for mesophyll and phloem mediated partial-resistance against aphids in a wild barley relative, which is effective against three aphid species, including two agricultural pests and an invasive species. Our data suggest the partialresistance in this progenitor of modern barley is complex and may be associated with elevated defence gene expression and reduced phloem quality.

\section{Mesophyll and phloem-based factors contribute to partial-resistance in Hsp5}

Our observation that $R$. padi feeding on Hsp5 spends more time in the pathway phase (probing into plant tissue) and takes longer to reach the phloem and initiate salivation/phloem ingestion is representative of feeding patterns associated with mesophyllbased resistance (Alvarez et al., 2006). Factors associated with mesophyll resistance are thought to antagonise and impede stylet penetration (Montllor and Tjallingii, 1989; Alvarez et al., 2006). In addition, R. padi spends less time ingesting phloem sap and salivating into the phloem, in line with resistance factors residing in the phloem (Alvarez et al., 2006). Phloem based resistance factors generally alter the ingestion efficiency of aphids and can involve feeding antagonists, alterations to the phloem metabolic profile, and the plugging of sievetube elements (Klingler et al., 1998; Klingler et al., 2005; Pegadaraju et al., 2007; Medina- 
Partial-resistance against aphids in other plant-aphid systems have similarly pointed to the importance of mesophyll and phloem-based resistance factors (Montllor and Tjallingii, 1989; Caillaud et al., 1995; Pegadaraju et al., 2007; Guo et al., 2012; Greenslade et al., 2016). For example, partial resistance in Triticum monococcum lines (a wild relative of wheat) against $S$. avenae and $R$. padi involved resistance at the phloem level, as determined by EPG (Caillaud et al., 1995; Greenslade et al., 2016). Interestingly, metabolic profiling of resistant and susceptible lines in the latter study indicated different metabolite profiles between susceptible and partially-resistant plants, including lower levels of primary metabolites in the partially-resistant lines and elevated Asn (Greenslade et al., 2016). Resistance against $D$. noxia in five cereal species was shown to involve phloem and mesophyll resistance factors, with elevated 2,4-dihydroxy-7-methoxy-1,4-benzoxazin-3-one (DIMBOA) levels hypothesised to be a contributing factor towards resistance (Mayoral et al., 1996). Resistance against $D$. noxia in wheat also involved individual resistance genes; the most recent of these to be characterised is Dn10 (Li et al., 2018), although the tissue types involved in conferring this resistance are unknown.

In addition, Arabidopsis thaliana defence against Myzus persicae involved phytoalexin deficient4 (PAD4), and reduced susceptibility in PAD4 overexpressing lines was associated with reduced phloem ingestion (Pegadaraju et al., 2007). Furthermore, gene-for-gene type resistance against the pea aphid, Acyrthosiphon pisum, in Medicago truncatula line Jemalong A17 (A17) is conferred by a single gene, RAP1, which maps to chromosome 3 (Stewart et al., 2009). Further characterisation showed that $A 17$ also conferred resistance against the bluegreen aphid, $A$. kondoi, as well as $A$. pisum, and that this resistance was phloem-mediated and linked to a QTL on chromosome 3 (Guo et al., 2012). The inorganic chemistry of leaf tissue can also play a role in plant defence (Lane, 2002; Boyd, 2012), with oxalates highlighted as important contributors towards plant defence against pathogens in cereals (Lane, 2002). The inorganic chemistry of Hsp5 and Concerto leaves was not assessed in this study, but a comparison of leaf chemistry could highlight further chemical groups which could be involved in mediating plant-aphid interactions. 
Leaf surface architectural differences were detected between Concerto and Hsp5 and included a higher abundance of non-glandular leaf trichomes in Hsp5 and a more complex chemistry in the epicuticular extracts of Concerto. Non-glandular trichomes have been reported to decrease R. padifitness in wheat (Roberts and Foster, 1983), but have contrasting effects on herbivore fitness in other plants. For example, the density of non-glandular trichomes in raspberry negatively affected spider mite performance but had minimal impact on aphid fitness (Karley et al., 2016).

Although we detected a positive correlation between trichome abundance and R. padi $r_{\mathrm{m}}$, there was no correlation between trichome abundance and juvenile $R$. padi mass gain, indicating that eithernon-glandular trichomes have differential effects on aphids at different life-stages or that the higher abundance of non-glandular trichomes on the leaf surface of Hsp5 are not a primary cause of partial-resistance to aphids. Indeed, EPG analysis indicated that leaf surface traits contributed little to partial-resistance in Hsp5. Aphids feeding from Hsp5 did not show increased time spent in the non-probing phase (a key indicator of epidermal-mediated resistance: Alvarez et al. (2006). Moreover, the time taken for aphids to penetrate the leaf surface was shorter on $\mathrm{Hsp} 5$, indicating aphids experienced fewer barriers to probing the leaf epidermis on Hsp5. Less complex chemistry at the leaf epicuticle in Hsp5 may have played a role in promoting aphid probing of plant tissue and previous studies have shown that epicuticular chemical compounds can either promote or deter aphid probing of plant tissue (Powell et al., 1999). Barley epicuticular waxes can contribute towards resistance against $R$. padi (Tsumuki et al., 1989), although the influence of specific chemical functional groups on aphid behaviour is not well characterised.

\section{Basal defence gene expression is elevated in Hsp5}

In line with Delp et al. (2009) and Mehrabi et al. (2014), basal expression levels of thionin genes, which contribute to barley defences against aphids (Escudero-Martinez et al., 2017), and LOX2, a JA-signalling marker, were elevated in Hsp5. The feeding parameters exhibited by $R$. padi while feeding on Hsp5 indicated that mesophyll-based mechanisms conferred short-term (6h) partial-resistance against aphids. Thionins are antimicrobial peptides present in plant cell walls and within the intracellular space (Reimann-Philipp et al., 1989; Stec, 2006). It is therefore likely that aphids are exposed to thionins when probing mesophyll tissue, and these could contribute to reduced aphid performance on Hsp5. 
In addition, several plant defence signalling genes, LOX (JA), ERF1 (ET) and A1 (ABA) showed to biotic stimuli. In line with our data, HvLOX2 genes and other components of the JA (HVAOS, HvAOC), ET (HvACCO, HvACCS), and Auxin (HvTDS, HvTSM) signalling pathways showed higher basal expression in the barley cultivar Stoneham, which is partially-resistant against $D$. noxia, relative to susceptible cultivar Otis (Marimuthu and Smith, 2012). Furthermore, overexpression of HVLOX2 in barley resulted in decreased $R$. padi fecundity five days after infestation (Losvik et al., 2017), pointing to a functional role of this gene and JA signalling in short-term barley defence against aphids. Expression levels of CmERF1 in early responses (6h) to aphid infestation were around ten-fold higher in a resistant variety of melon compared with a susceptible variety (Anstead et al., 2010), and higher ET levels have been reported to contribute to $R$. maidis resistance in maize (Louis et al., 2015). ABA mediated-processes have been implicated in increasing both plant resistance (Zhu-Salzman et al., 2004; Park et al., 2006) and susceptibility (Kerchev et al., 2013; Hillwig et al., 2016) to aphids. Therefore the consequence of elevated HvA1 in the context of partial aphid resistance in Hsp5 is not clear. Guo et al. (2016) reported that elevated ABA levelsin response to drought conditions can lead to increased aphid xylem ingestion. This finding suggests that elevated expression of components of the ABA signalling pathway could indirectly contribute to partial-resistance by encouraging xylem ingestion, thereby reducing phloem ingestion. Indeed, longer periods of xylem ingestion were detected in $\mathrm{R}$. padi feeding from $\mathrm{Hsp5}$, indicating that there may be potential fitness consequences for aphids as a result of higher basal expression levels.

In contrast, basal expression levels of HVNPR1, a SA-signalling marker, were not significantly different between Hsp5 and Concerto. However, HVNPR1 levels in Concerto were downregulated $24 \mathrm{~h}$ after aphid infestation to a level that was significantly lower than HVNPR1 levels in $\mathrm{Hsp} 5$ after 24h of aphid infestation. Therefore, SA-mediated defences in Concerto, but not Hsp5, may be repressed upon aphid infestation leading to increased susceptibility of this cultivar. Indeed, NPR1 is required for initiation of SA-mediated defence against aphids in $A$. thaliana (Moran and Thompson, 2001; Wu et al., 2012). phloem of Hsp5 compared with Concerto could be associated with lower aphid performance. 
Alterations to amino acid composition can reduce plant palatability and nutritional quality and contribute to increased resistance against aphids (Sandström and Pettersson, 1994; Ponder et al., 2000; Karley et al., 2002). For example, decreased survival and fecundity of $M$. persicae and Macrosiphum euphorbiae feeding from older "tuber-filling" potato plants compared with younger "pre-tuber-filling" plants was linked to changes in amino acid composition (Karley et al., 2002). When presented with chemically-defined diets representative of the phloem sap composition of young and mature potato plants, $M$. persicae and Ma. euphorbiae showed decreased feeding rate on the "tuber-filling" diets (Karley et al., 2002). In addition, $R$. padi feeding from barley plants grown under nitrogenlimited conditions exhibited reduced $r_{m}$ compared with $R$. padifeeding on barley grown under nitrogen-rich conditions (Ponder et al., 2000). Examination of phloem amino acid composition indicated that composition was altered under nitrogen-limited conditions. Interestingly, plants under nitrogen-limited conditions contained a higher percentage of Asn, a lower percentage of Gly and a small reduction in the concentration of essential amino acids compared with nitrogen-fertilised plants (Ponder et al., 2000).

Changes in the abundance of specific amino acids cannot be readily associated with increased insect resistance/susceptibility in a given plant species. It is most likely that any observed effect on aphid fitness is due primarily to the ratio of essential:non-essential amino acids as a result of compositional changes. Indeed, essential amino acids are generally elevated in susceptible plants compared with varieties showing increased resistance against aphids (Auclair, 1976). Vogel and Moran (2011) found that the mass of multiple A. pisum biotypes was reduced when essential amino acids were removed from aphid artificial diets; this was observed even though aphids have the capacity to synthesis essential amino acids via their essential endosymbiont, Buchnera aphidicola (Douglas and Prosser, 1992). Furthermore, some aphid species actively remobilise plant nutrients to increase the abundance of essential amino acids in susceptible plant hosts (Telang et al., 1999; Sandström et al., 2000). Enhanced mobilisation of plant nutrients is thought to be the mechanism explaining resistance breakdown in wheat by a virulent biotype of the greenbug, Schizaphis graminum (Dorschner et al., 1987). In a study by Sandström et al. (2000), R. padi feeding did not lead to increased phloem mobilisation of amino acids, similar to observations made in our experimental system 
where $R$. padi infestation did not alter the phloem amino acid composition in Hsp5 or Concerto.

\section{Conclusion}

This study shows that partial-resistance against aphids in wild barley can be wide-ranging and effective against multiple aphid species. Broad partial-resistance traits are agriculturally and economically important as crops are likely to be infested by multiple insect species under field conditions (Stam et al., 2014). However, compared with gene-for-gene resistance traits, comparatively little is known about the genetic determinants of partial-resistance. The underlying factors contributing towards partial-resistance are complex and likely to involve multiple, independent resistance pathways (Mayoral et al., 1996; Moharramipour et al., 1997; Seah et al., 1998). We show that partial-resistance against aphids in wild barley involves resistance factors that reside in both the mesophyll and vascular tissues. This partialresistance is potentially caused by heightened basal expression of defence and phytohormone signalling genes, alongside altered phloem amino acid quality. However, the functional molecular role of these differences, and how they contribute towards partialresistance, remains to be established.

\section{Supplementary Data}

Supplementary Table 1: primers used in RT-qPCR analysis.

Supplementary Table 2: Additional EPG parameters.

Supplementary Table 3: FTIR results for leaf surface extracts

Supplementary Fig. 1: Correlation of insect fitness with non-glandular trichome density.

\section{Acknowledgements}

D.J.L was funded by the James Hutton Institute and the Universities of Aberdeen and Dundee through a Scottish Food Security Alliance (Crops) PhD studentship. A.J.K, T.A.V, A.H.J.R, A.M.M, and E.P-F were supported by the strategic research programme funded by the 
622 Scottish Government's Rural and Environment Science and Analytical Services Division. J.I.B.B.

623 was supported by the European Research Council (310190-APHIDHOST). We would like to thank

624 Dr Freddy Tjallingii (EPG Systems, The Netherlands), Professor Alberto Fereres (CSIC, Spain)

625 and Professor Gregory Walker (University of California, Riverside, USA) for providing EPG

626 training and Gaynor Malloch (James Hutton Institute) for kindly providing COI barcoding

627 primers.

628

629 Author Contributions

630 JIBB, AJK, and DJL conceived and designed the experiments. DJL, EP-F, and AMM performed

631 the experiments. JIBB, AJK, DJL, and JAHR analysed the data. DJL wrote the manuscript with

632 input from JIBB, AJK, TAV, and JAHR. All authors read and approved the final manuscript. 


\section{References}

Agrawal, A. A., Fishbein, M., Jetter, R., Salminen, J. P., Goldstein, J. B., Freitag, A. E. and Sparks, J. P. (2009). Phylogenetic ecology of leaf surface traits in the milkweeds (Asclepias spp.): chemistry, ecophysiology, and insect behavior. New Phytologist 183, 848-67.

Ahmad, S., Veyrat, N., Gordon-Weeks, R., Zhang, Y., Martin, J., Smart, L., Glauser, G., Erb, M., Flors, V., Frey, M. et al. (2011). Benzoxazinoid Metabolites Regulate Innate Immunity against Aphids and Fungi in Maize. Plant Physiology 157, 317-327.

Åhman, I., Tuvesson, S. and Johansson, M. (2000). Does Indole Alkaloid Gramine Confer Resistance in Barley to Aphid Rhopalosiphum Padi? Journal of Chemical Ecology 26, 233-255.

Alexandratos, N. and Bruinsma, J. (2012). World Agriculture Towards 2030/2050: the 2012 Revision. ESA Working Paper No. 12-03. Rome: FAO.

Alvarez, A. E., Tjallingii, W. F., Garzo, E., Vleeshouwers, V., Dicke, M. and Vosman, B. (2006). Location of resistance factors in the leaves of potato and wild tuber-bearing Solanum species to the aphid Myzus persicae. Entomologia Experimentalis et Applicata 121, 145-157.

Anstead, J., Samuel, P., Song, N., Wu, C., Thompson, G. A. and Goggin, F. (2010). Activation of ethylene-related genes in response to aphid feeding on resistant and susceptible melon and tomato plants. Entomologia Experimentalis et Applicata 134, 170-181.

Arad ottir, G. I., Martin, J. L., Clark, S. J., Pickett, J. A. and Smart, L. E. (2017). Searching for wheat resistance to aphids and wheat bulb fly in the historical Watkins and Gediflux wheat collections. Annals of Applied Biology 170, 179-188.

Auclair, J. L. (1963). Aphid Feeding and Nutrition. Annual Review of Entomology 8, 439-490.

Auclair, J. L. (1976). Feeding and Nutrition of the Pea Aphid, Acyrthosiphon Pisum (Harris), with Special Reference to Amino Acids. In The Host-Plant in Relation to Insect Behaviour and

Reproduction, (ed. T. Jermy), pp. 29-34. Boston, MA: Springer US.

Bari, R. and Jones, J. D. G. (2009). Role of plant hormones in plant defence responses. Plant Mol Biol 69, 473-488.

Barria, B. N., Copaja, S. V. and Niemeyer, H. M. (1992). Occurrence of DIBOA in wild Hordeum species and its relation to aphid resistance. Phytochemistry 31, 89-91.

Boyd, R. S. (2012). Plant defense using toxic inorganic ions: Conceptual models of the defensive enhancement and joint effects hypotheses. Plant Science 195, 88-95.

Caillaud, C. M., Pierre, J. S., Chaubet, B. and Pietro, J. P. (1995). Analysis of wheat resistance to the cereal aphid Sitobion avenae using electrical penetration graphs and flow charts combined with correspondence analysis. Entomologia Experimentalis et Applicata 75, 9-18.

Chandrasekhar, K., Shavit, R., Distelfeld, A., Christensen, S. A. and Tzin, V. (2018). Exploring the metabolic variation between domesticated and wild tetraploid wheat genotypes in response to corn leaf aphid infestation. Plant Signaling \& Behavior https://doi.10.1080/15592324.2018.1486148. Chen, M.-h., Han, Z.-j., Qiao, X.-f. and Qu, M.-j. (2007). Mutations in acetylcholinesterase genes of Rhopalosiphum padi resistant to organophosphate and carbamate insecticides. Genome 50, 172179.

Delp, G., Gradin, T., Åhman, I. and Jonsson, L. M. (2009). Microarray analysis of the interaction between the aphid Rhopalosiphum padi and host plants reveals both differences and similarities between susceptible and partially resistant barley lines. Molecular Genetics and Genomics 281, 233248.

Dempewolf, H., Eastwood, R. J., Guarino, L., Khoury, C. K., Müller, J. V. and Toll, J. (2014). Adapting Agriculture to Climate Change: A Global Initiative to Collect, Conserve, and Use Crop Wild Relatives. Agroecology and Sustainable Food Systems 38, 369-377.

Dewar, A. M. and Foster, S. P. (2017). Overuse of Pyrethroids may be implicated in the Recent BYDV Epidemics in Cereals. Outlooks on Pest Management 28, 7-12.

Dinno, A. (2017). dunn.test: Dunn's Test of Multiple Comparisons Using Rank Sums. CRAN repository available: https://CRAN.R-project.org/package=dunn.test. 
Directive. (2009/128/EC). Directive 2009/128/EC of the European Parliament and of the Council of 21 October 2009 establishing a framework for Community action to achieve the sustainable use of pesticides.

Dorschner, K. W., Ryan, J. D., Johnson, R. C. and Eikenbary, R. D. (1987). Modification of Host Nitrogen Levels by the Greenbug (Homoptera: Aphididae): Its Role in Resistance of Winter Wheat to Aphids. Environmental Entomology 16, 1007-1011.

Douglas, A. E. and Prosser, W. A. (1992). Synthesis of the essential amino acid tryptophan in the pea aphid (Acyrthosiphon pisum) symbiosis. Journal of Insect Physiology 38, 565-568.

Escudero-Martinez, C. M., Morris, J. A., Hedley, P. E. and Bos, J. I. B. (2017). Barley transcriptome analyses upon interaction with different aphid species identify thionins contributing to resistance. Plant, Cell \& Environment 40, 2628-2643.

Folmer, O., Black, M., Hoeh, W., Lutz, R. and Vrijenhoek, R. (1994). DNA primers for amplification of mitochondrial cytochrome c oxidase subunit I from diverse metazoan invertebrates. Molecular Marine Biology Biotechnology 3, 294-299.

Forslund, K., Pettersson, J., Bryngelsson, T. and Jonsson, L. (2000). Aphid infestation induces PRproteins differently in barley susceptible or resistant to the bird cherry-oat aphid (Rhopalosiphum padi). Physiologia Plantarum 110, 496-502.

Foster, S. P., Paul, V. L., Slater, R., Warren, A., Denholm, I., Field, L. M. and Williamson, M. S. (2014). A mutation (L1014F) in the voltage-gated sodium channel of the grain aphid, Sitobion avenae, is associated with resistance to pyrethroid insecticides. Pest Management Science 70, 12491253.

Foyer, C. H., Rasool, B., Davey, J. W. and Hancock, R. D. (2016). Cross-tolerance to biotic and abiotic stresses in plants: a focus on resistance to aphid infestation. Journal of experimental botany 67, 2025-2037.

Gianoli, E. and Niemeyer, H. M. (1998). DIBOA in wild Poaceae: Sources of resistance to the Russian wheat aphid (Diuraphis noxia) and the greenbug (Schizaphis graminum). Euphytica 102, 317-321.

Gibson, R. W. and Pickett, J. A. (1983). Wild potato repels aphids by release of aphid alarm pheromone. Nature 302, 608-609.

Glas, J. J., Schimmel, B. C., Alba, J. M., Escobar-Bravo, R., Schuurink, R. C. and Kant, M. R. (2012). Plant glandular trichomes as targets for breeding or engineering of resistance to herbivores.

International Journal of Molecular Sciences 13, 17077-17103.

Greenslade, A. F. C., Ward, J. L., Martin, J. L., Corol, D. I., Clark, S. J., Smart, L. E. and Aradottir, G. I. (2016). Triticum monococcum lines with distinct metabolic phenotypes and phloem-based partial resistance to the bird cherry-oat aphid Rhopalosiphum padi. Annals of Applied Biology 168, 435-449. Guan, W., Ferry, N., Edwards, M. G., Bell, H. A., Othman, H., Gatehouse, J. A. and Gatehouse, A. M. R. (2015). Proteomic analysis shows that stress response proteins are significantly up-regulated in resistant diploid wheat (Triticum monococcum) in response to attack by the grain aphid (Sitobion avenae). Molecular Breeding https://doi.org/10.1007/s11032-015-0220-x.

Guo, H., Sun, Y., Peng, X., Wang, Q., Harris, M. and Ge, F. (2016). Up-regulation of abscisic acid signaling pathway facilitates aphid xylem absorption and osmoregulation under drought stress. Journal of experimental botany 67, 681-693.

Guo, S.-M., Kamphu is, L. G., Gao, L.-L., Klingler, J. P., Lichtenzveig, J., Edwards, O. and Singh, K. B. (2012). Identification of distinct quantitative trait loci associated with defence against the closely related aphids Acyrthosiphon pisum and A. kondoi in Medicago truncatula. Journal of experimental botany 63, 3913-3922.

Hillwig, M. S., Chiozza, M., Casteel, C. L., Lau, S. T., Hohenstein, J., Hernández, E., Jander, G. and Maclntosh, G. C. (2016). Abscisic acid deficiency increases defence responses against Myzus persicae in Arabidopsis. Molecular Plant Pathology 17, 225-235.

Hua, W., Zhu, J., Shang, Y., Wang, J., Jia, Q. and Yang, J. (2015). Identification of Suitable Reference Genes for Barley Gene Expression Under Abiotic Stresses and Hormonal Treatments. Plant Molecular Biology Reporter 33, 1002-1012. 
Hui, W., Gel, Y. R. and Gastwirth, J. L. (2008). lawstat: An R Package for Law, Public Policy and Biostatistics. Journal of Statistical Software 28, 1-26.

James, K. L., Randall, N. P., Walters, K. F. A., Haddaway, N. R. and Land, M. (2016). Evidence for the effects of neonicotinoids used in arable crop production on non-target organisms and concentrations of residues in relevant matrices: a systematic map protocol. Environmental Evidence https://doi.org/10.1186/s13750-016-0072-9.

Jess, S., Matthews, D., Murchie, A. and Lavery, M. (2018). Pesticide Use in Northern Ireland's Arable Crops from 1992-2016 and Implications for Future Policy Development. Agriculture https://doi.org/10.3390/agriculture8080123.

Jones, B. N., Pääbo, S. and Stein, S. (1981). Amino Acid Analysis and Enzymatic Sequence Determination of Peptides by an Improved o-Phthaldialdehyde Precolumn Labeling Procedure. Journal of Liquid Chromatography 4, 565-586.

Karley, A. J., Douglas, A. E. and Parker, W. E. (2002). Amino acid composition and nutritional quality of potato leaf phloem sap for aphids. Journal of Experimental Biology 205, 3009-3018.

Karley, A. J., Mitchell, C., Brookes, C., McNicol, J., O'Neill, T., Roberts, H., Graham, J. and Johnson, S. N. (2016). Exploiting physical defence traits for crop protection: leaf trichomes of Rubus idaeus have deterrent effects on spider mites but not aphids. Annals of Applied Biology 168, 159-172. Kassambara, A. and Kosinski, M. (2017). survminer: Drawing Survival Curves using "ggplot". CRAN repository available: https://cran.r-project.org/web/packages/survminer/index.html.

Kerchev, P. I., Karpińska, B., Morris, J. A., Hussain, A., Verrall, S. R., Hedley, P. E., Fenton, B., Foyer, C. H. and Hancock, R. D. (2013). Vitamin C and the Abscisic Acid-Insensitive 4 Transcription Factor Are Important Determinants of Aphid Resistance in Arabidopsis. Antioxidants \& Redox Signaling 18, 2091-2105.

King, R. W. and Zeevaart, J. A. D. (1974). Enhancement of Phloem Exudation from Cut Petioles by Chelating Agents. Plant Physiology 53, 96-103.

Klingler, J., Creasy, R., Gao, L., Nair, R. M., Calix, A. S., Jacob, H. S., Edwards, O. R. and Singh, K. B. (2005). Aphid Resistance in Medicago truncatula Involves Antixenosis and Phloem-Specific, Inducible Antibiosis, and Maps to a Single Locus Flanked by NBS-LRR Resistance Gene Analogs. Plant Physiology 137, 1445-1455.

Klingler, J., Powell, G., Thompson, G. A. and Isaacs, R. (1998). Phloem specific aphid resistance in Cucumis melo line AR 5: effects on feeding behaviour and performance of Aphis gossypii.

Entomologia Experimentalis et Applicata 86, 79-88.

Kuznetsova, A., Brockhoff, P. B. and Christensen, R. H. B. (2017). ImerTest package: tests in linear mixed effects models. Journal of Statistical Software 82, 1-26.

Lane, B. G. (2002). Oxalate, Germins, and Higher-Plant Pathogens. IUBMB Life 53, 67-75.

Lenth, R. V. (2016). Least-Squares Means: The R Package Ismeans. Journal of Statistical Software 69, 1-33.

Leybourne, D. J., Bos, J. I. B., Valentine , T. A. and Karley, A. J. (2018). The price of protection: a defensive endosymbiont impairs nymph growth in the bird cherry-oat aphid, Rhopalosiphum padi. Insect Science https://doi.org/10.1111/1744-7917.12606

Li, G., Xu, X., Carver, B. F., Guo, P. and Puterka, G. (2018). Dn10, a New Gene Conferring Resistance to Russian Wheat Aphid Biotype 2 in Iranian Wheat Landrace PI 682675. Crop Science https://doi.org/10.2135/cropsci2017.10.0649.

Livak, K. J. and Schmittgen, T. D. (2001). Analysis of Relative Gene Expression Data Using Real-Time Quantitative PCR and the 2- $\Delta \Delta C T$ Method. Methods 25, 402-408.

Losvik, A., Beste, L., Glinwood, R., Ivarson, E., Stephens, J., Zhu, L. -H. and Jonsson, L. (2017).

Overexpression and Down-Regulation of Barley Lipoxygenase LOX2.2 Affects Jasmonate-Regulated Genes and Aphid Fecundity. International Journal of Molecular Sciences

https://doi:10.3390/ijms18122765. 
Louis, J., Basu, S., Varsani, S., Castano-Duque, L., Jiang, V., Williams, W. P., Felton, G. W. and Luthe, D.S. (2015). Ethylene Contributes to maize insect resistance1-Mediated Maize Defense against the Phloem Sap-Sucking Corn Leaf Aphid. Plant Physiology 169, 313-324.

Maag, D., Erb, M., Kollner, T. G. and Gershenzon, J. (2015). Defensive weapons and defense signals in plants: some metabolites serve both roles. Bioessays 37, 167-74.

MacGillivray, M. and Anderson, G. (1957). Three useful insect cages. The Canadian Entomologist 89, 43-46.

Marimuthu, M. and Smith, C. M. (2012). Barley tolerance of Russian wheat aphid (Hemiptera: Aphididae) biotype 2 herbivory involves expression of defense response and developmental genes. Plant Signaling \& Behavior 7, 382-391.

Mayoral, A. M., Tjallingii, W. F. and Castañera, P. (1996). Probing behaviour of Diuraphis noxia on five cereal species with different hydroxamic acid levels. Entomologia Experimentalis et Applicata 78, 341-348.

Medina-Ortega, K. J. and Walker, G.P. (2015). Faba bean forisomes can function in defence against generalist aphids. Plant, Cell \& Environment 38, 1167-1177.

Mehrabi, S., Åhman, I. and Jonsson, L. M. V. (2014). Transcript abundance of resistance- and susceptibility-related genes in a barley breeding pedigree with partial resistance to the bird cherryoat aphid (Rhopalosiphum padi L.). Euphytica 198, 211-222.

Mitchell, C., Brennan, R. M., Graham, J. and Karley, A. J. (2016). Plant Defense against Herbivorous Pests: Exploiting Resistance and Tolerance Traits for Sustainable Crop Protection. Frontiers in Plant Science 7, https://doi.org/10.3389/fpls.2016.01132.

Moharramipour, S., Tsumuki, H., Sato, K. and Yoshida, H. (1997). Mapping resistance to cereal aphids in barley. Theoretical and Applied Genetics 94, 592-596.

Montllor, C. B. and Tjallingii, W. F. (1989). Stylet penetration by two aphid species on susceptible and resistant lettuce. Entomologia Experimentalis et Applicata 52, 103-111.

Moran, P. J. and Thompson, G. A. (2001). Molecular Responses to Aphid Feeding in Arabidopsis in Relation to Plant Defense Pathways. Plant Physiology 125, 1074-1085.

Moreira, X., Abdala-Roberts, L., Gols, R. and Francisco, M. (2018). Plant domestication decreases both constitutive and induced chemical defences by direct selection against defensive traits.

Scientific Reports https://doi.org/10.1038/s41598-018-31041-0.

Morkunas, I., Mai, V. C. and Gabryś, B. (2011). Phytohormonal signaling in plant responses to aphid feeding. Acta Physiologiae Plantarum 33, 2057-2073.

Morris, J. G. (1991). Nutrition. In Environmental and Metabolic Animal Physiology, (ed. C. L. Prosser), pp. 231 - 276. New York, USA: John Wiley \& Sons.

Murray, G. M. and Brennan, J. P. (2010). Estimating disease losses to the Australian barley industry. Australasian Plant Pathology 39, 85-96.

Newman, C. and Newman, R. (2006). A brief history of barley foods. Cerealfoods world 51, 4-7. Newton, A. C., Flavell, A. J., George, T. S., Leat, P., Mullholland, B., Ramsay, L., Revoredo-Giha, C., Russell, J., Steffenson, B. J., Swanston, J. S. et al. (2011). Crops that feed the world 4. Barley: a resilient crop? Strengths and weaknesses in the context of food security. Food Security https://doi.org/10.1007/s12571-011-0126-3.

Nieto-Lopez, R. M. and Blake, T. K. (1994). Russian Wheat Aphid Resistance in Barley: Inheritance and Linked Molecular Markers. Crop Science 34, 655-659.

Oksanen, J., Blanchet, F. G., Kindt, R., Legendre, P., Minchin, P. R., O'hara, R., Simpson, G. L., Solymos, P., Stevens, M. H. H. and Wagner, H. (2013). R Package vegan: Community Ecology Package. CRAN repository available: https://CRAN.R-project.org/package=vegan.

Park, S.-J., Huang, Y. and Ayoubi, P. (2006). Identification of expression profiles of sorghum genes in response to greenbug phloem-feeding using cDNA subtraction and microarray analysis. Planta 223, 932-947.

Pegadaraju, V., Louis, J., Singh, V., Reese, J. C., Bautor, J., Feys, B. J., Cook, G., Parker, J. E. and Shah, J. (2007). Phloem-based resistance to green peach aphid is controlled by Arabidopsis 
PHYTOALEXIN DEFICIENT4 without its signaling partner ENHANCED DISEASE SUSCEPTIBILITY1. Plant J 52, 332-41.

Peng, H. C. and Walker, G. P. (2018). Sieve element occlusion provides resistance against Aphis gossypii in TGR-1551 melons. Insect Science https://doi.org/10.1111/1744-7917.12610.

Perry, K. L., Kolb, F. L., Sammons, B., Lawson, C., Cisar, G. and Ohm, H. (2000). Yield Effects of Barleyyellow dwarf virus in Soft Red Winter Wheat. Phytopathology 90, 1043-1048.

Pomeranz, M., Campbell, J., Siegal-Gaskins, D., Engelmeier, J., Wilson, T., Fernandez, V., Brkljacic, J. and Grotewold, E. (2013). High-resolution computational imaging of leaf hair patterning using polarized light microscopy. The Plant Journal 73, 701-708.

Ponder, K. L., Pritchard, J., Harrington, R. and Bale, J. S. (2000). Difficulties in location and acceptance of phloem sap combined with reduced concentration of phloem amino acids explain lowered performance of the aphid Rhopalosiphum padi on nitrogen deficient barley (Hordeum vulgare) seedlings. Entomologia Experimentalis et Applicata 97, 203-210.

Powell, G. (2005). Intracellular salivation is the aphid activity associated with inoculation of nonpersistently transmitted viruses. Journal of General Virology 86, 469-72.

Powell, G., Maniar, S. P., Pickett, J. A. and Hardie, J. (1999). Aphid responses to non-host epicuticular lipids. Entomologia Experimentalis et Applicata 91, 115-123.

Reimann-Philipp, U., Schrader, G., Martin oia, E., Barkholt, V. and Apel, K. (1989). Intracellular thionins of barley. A second group of leaf thionins closely related to but distinct from cell wall-bound thionins. Journal of Biological Chemistry 264, 8978-8984.

Roberts, J. J. and Foster, J. E. (1983). Effect of Leaf Pubescence in Wheat on the Bird Cherry Oat Aphid (Homoptera: Aphidae). Journal of Economic Entomology 76, 1320-1322.

Sandström, J. and Pettersson, J. (1994). Amino acid composition of phloem sap and the relation to intraspecific variation in pea aphid (Acyrthosiphon pisum) performance. Journal of Insect Physiology 40, 947-955.

Sandström, J., Telang, A. and Moran, N. A. (2000). Nutritional enhancement of host plants by aphids - a comparison of three aphid species on grasses. Journal of Insect Physiology 46, 33-40.

Seah, S., Sivasith amparam, K., Karakousis, A. and Lagudah, E. S. (1998). Cloning and characterisation of a family of disease resistance gene analogs from wheat and barley. Theoretical and Applied Genetics 97, 937-945.

Smith, C. M. and Boyko, E. V. (2007). The molecular bases of plant resistance and defense responses to aphid feeding: current status. Entomologia Experimentalis et Applicata 122, 1-16.

Smith, P. and Sward, R. (1982). Crop loss assessment studies on the effects of barley yellow dwarf virus in wheat in Victoria. Australian Journal of Agricultural Research 33, 179-185.

Stam, J. M., Kroes, A., Li, Y., Gols, R., Loon, J. J. A. V., Poelman, E. H. and Dicke, M. (2014). Plant Interactions with Multiple Insect Herbivores: From Community to Genes. Annual Review of Plant Biology 65, 689-713.

Stec, B. (2006). Plant thionins - the structural perspective. Cellular and Molecular Life Sciences 63, 1370-1385.

Stewart, S. A., Hodge, S., Ismail, N., Mansfield, J. W., Feys, B. J., Prospéri, J.-M., Huguet, T., Ben, C., Gentzbittel, L. and Powell, G. (2009). The RAP1 Gene Confers Effective, Race-Specific Resistance to the Pea Aphid in Medicago truncatula Independent of the Hypersensitive Reaction. Molecular PlantMicrobe Interactions 22, 1645-1655.

Tang, Y., Horikoshi, M. and Li, W. (2016). ggfortify: Unified Interface to Visualize Statistical Result of Popular R Packages. The R Journal 8, 478 - 489.

Telang, A., Sandström, J., Dyreson, E. and Moran, N. A. (1999). Feeding damage by Diuraphis noxia results in a nutritionally enhanced phloem diet. Entomologia Experimentalis et Applicata 91, $403-$ 412.

Therneau, T. (2018). coxme: Mixed effects Cox models. CRAN repository available: https://cran.rproject.org/web/packages/coxme/index.html. 
Therneau, T. M. and Grambsch, P. M. (2000). Modeling Survival Data: Extending the Cox Model. New York: Springer.

Tjallingii, W. (2001). Comparison of AC and DC systems for electronic monitoring of stylet penetration activities by homopterans. In Principles and applications of electronic monitoring and other techniques in the study of homopteran feeding behavior, eds. G. P. Walker and E. A. Backus), pp. 41. Beijin, China.

Tjallingii, W. (1991). Continuous recording of stylet penetration activities by aphids. In Aphid-Plant Genotype Interactions, eds. C. RK and E. RD), pp. 89 - 101. New York, USA: Elsevier.

Tjallingii, W. (1988). Electrical Recording of Stylet Penetration Activities. In Aphids Their Biology, Natural Enemies and Control, eds. M. AK and H. P), pp. 95 - 108. Amsterdam, The Netherlands: Elsevier.

Tjallingii, W. F. (1978). Electronic recording of penetration behaviour by aphids. Entomologia Experimentalis et Applicata 24, 721-730.

Tsumuki, H., Kanehisa, K. and Kawada, K. (1989). Leaf surface wax as a possible resistance factor of barley to cereal aphids. Applied Entomology and Zoology 24, 295-301.

Unal, G. and Jepson, P. C. (1991). The toxicity of aphicide residues to beneficial invertebrates in cereal crops. Annals of Applied Biology 118, 493-502.

Vandesompele, J., De Preter, K., Pattyn, F., Poppe, B., Van Roy, N., De Paepe, A. and Speleman, F. (2002). Accurate normalization of real-time quantitative RT-PCR data by geometric averaging of multiple internal control genes. Genome Biology and Evolution https://doi.org/10.1186/gb-2002-37-research0034.

Vogel, K. J. and Moran, N. A. (2011). Sources of variation in dietary requirements in an obligate nutritional symbiosis. Proceedings of the Royal Society B: Biological Sciences 278, 115-121.

Wu, Y., Zhang, D., Chu, Jee Y., Boyle, P., Wang, Y., Brindle, Ian D., De Luca, V. and Després, C. (2012). The Arabidopsis NPR1 Protein Is a Receptor for the Plant Defense Hormone Salicylic Acid. Cell Reports 1, 639-647.

Xu, X., Bai, G., Carver, B. F., Zhan, K., Huang, Y. and Mornhinweg, D. (2015). Evaluation and Reselection of Wheat Resistance to Russian Wheat Aphid Biotype 2. Crop Science 55, 695-701.

Zadoks, J. C., Chang, T. T. and Konzak, C. F. (1974). A decimal code for the growth stages of cereals. Weed Research 14, 415-421.

Zhang, H., Mittal, N., Leamy, L. J., Barazani, O. and Song, B.-H. (2017). Back into the wild-Apply untapped genetic diversity of wild relatives for crop improvement. Evolutionary Applications 10, 524.

Zhu-Salzman, K., Salzman, R. A., Ahn, J.-E. and Koiwa, H. (2004). Transcriptional Regulation of Sorghum Defense Determinants against a Phloem-Feeding Aphid. Plant Physiology 134, 420-431. 


\section{Tables}

Table 1: Statistical results of aphid performance experiments (significant values are shown in bold).

\begin{tabular}{|c|c|c|c|c|c|c|}
\hline $\begin{array}{l}\text { Response } \\
\text { Variable }\end{array}$ & $\begin{array}{c}\text { Explanatory } \\
\text { Variable }\end{array}$ & Model Basis & $\begin{array}{c}\text { Error } \\
\text { Distribution } \\
\text { or Statistical } \\
\text { Method }\end{array}$ & Statistical Test & $\begin{array}{c}\text { Test } \\
\text { Statistic }\end{array}$ & Pvalue \\
\hline $\begin{array}{l}\text { Nymph } \\
\text { Survival }\end{array}$ & $\begin{array}{c}\text { Plant } \\
\text { Aphid } \\
\text { Plant x Aphid }\end{array}$ & $\begin{array}{c}\text { Cox } \\
\text { Proportional } \\
\text { Hazards } \\
\text { Regression }\end{array}$ & $\mathrm{N} / \mathrm{A}$ & $\begin{array}{c}\text { Type ll Wald } \chi^{2} \\
\text { Analysis of } \\
\text { Deviance }\end{array}$ & $\begin{array}{l}X^{2}{ }_{1}=10.65 \\
X^{2}{ }_{2}=13.94 \\
X^{2}{ }_{2}=5.85\end{array}$ & $\begin{array}{l}<0.001 \\
0.054\end{array}$ \\
\hline \multirow[b]{2}{*}{$\begin{array}{c}\text { Nymph } \\
\text { mass gain } \\
\text { (mg) }\end{array}$} & Plant & \multirow{5}{*}{$\begin{array}{l}\text { Linear } \\
\text { Mixed } \\
\text { Effects } \\
\text { Model }\end{array}$} & \multirow{5}{*}{$\begin{array}{l}\text { Restricted } \\
\text { Maximum } \\
\text { Likelihood }\end{array}$} & \multirow{5}{*}{$\begin{array}{c}\text { Type III Analysis } \\
\text { of Variance } \\
\text { with } \\
\text { Satterthwaite } \\
\text { approximation } \\
\text { for degrees of } \\
\text { freedom }\end{array}$} & $F_{1,56}=9.14$ & 0.004 \\
\hline & $\begin{array}{c}\text { Aphid } \\
\text { Plant x Aphid }\end{array}$ & & & & $\begin{array}{l}F_{2,56}=49.83 \\
F_{2,46}=3.12\end{array}$ & $\begin{array}{l}<0.001 \\
0.054\end{array}$ \\
\hline \multirow{3}{*}{$\begin{array}{c}\text { Rate of } \\
\text { population } \\
\text { increase } \\
\left(r_{\mathrm{m}}\right)\end{array}$} & Plant & & & & $F_{1,54}=27.43$ & $<0.001$ \\
\hline & Aphid & & & & $F_{2,54}=99.10$ & $<0.001$ \\
\hline & Plant x Aphid & & & & $F_{2,52}=1.49$ & 0.234 \\
\hline
\end{tabular}


Table 2: Statistical results of the significant EPG parameters. The mean value for each plant host and the standard error of the mean are also displayed; in the test statistic column $\chi^{2}$ values are italicised and $F$ values are underlined.

\begin{tabular}{|c|c|c|c|c|c|c|c|c|c|c|}
\hline \multirow{2}{*}{ EPG Parameter } & \multirow{2}{*}{$\begin{array}{l}\text { Hypothesised location } \\
\text { of resistance factor }\end{array}$} & \multirow{2}{*}{ Transformation } & \multicolumn{2}{|c|}{ Mean Value } & \multicolumn{2}{|c|}{$\begin{array}{c}\text { Standard Error of the } \\
\text { Mean }\end{array}$} & \multirow{2}{*}{ Statistical Test } & \multirow{2}{*}{$\begin{array}{c}\text { Test } \\
\text { Statistic }\end{array}$} & \multirow{2}{*}{$\begin{array}{l}\text { Degrees of } \\
\text { Freedom } \\
\text { (Residuals) }\end{array}$} & \multirow{2}{*}{ P Value } \\
\hline & & & $\begin{array}{c}\text { cv. } \\
\text { Concerto }\end{array}$ & HsP5 & $\begin{array}{c}\text { cv. } \\
\text { Concerto }\end{array}$ & HsP5 & & & & \\
\hline All parameters (Global analysis) & All tissue & - & - & - & - & - & $\begin{array}{l}\text { Permutated } \\
\text { Multiple } \\
\text { Analysis of } \\
\text { Variance }\end{array}$ & $\underline{2.61}$ & $1(33)$ & 0.022 \\
\hline Duration of the first aphid probe & Mesophyll & $\log [10]$ & $7717 \mathrm{~s}$ & $2147 s$ & $1737 \mathrm{~s}$ & $1161 \mathrm{~s}$ & ANOVA & $\underline{6.94}$ & $1(33)$ & 0.013 \\
\hline $\begin{array}{l}\text { Number of potential drops } \\
\text { (intracellular punctures) in first } \\
\text { probe }\end{array}$ & Mesophyll & Sqrt & 24 & 10 & 5.36 & 2.82 & ANOVA on $\mathrm{glm}$ & 3.95 & $1(33)$ & 0.047 \\
\hline $\begin{array}{l}\text { Time to the first E1 phase (sieve } \\
\text { element puncture and salivation } \\
\text { into phloem) }\end{array}$ & Mesophyll & $\log [2]$ & $2856 \mathrm{~s}$ & $7452 \mathrm{~s}$ & $660 \mathrm{~s}$ & $1683 \mathrm{~s}$ & ANOVA & $\underline{6.33}$ & $1(33)$ & 0.017 \\
\hline $\begin{array}{l}\text { Time to the first phloem phase } \\
\text { containing E1 and/or E2 }\end{array}$ & Mesophyll & - & $3761 \mathrm{~s}$ & $9864 \mathrm{~s}$ & $675 \mathrm{~s}$ & $1884 \mathrm{~s}$ & $\begin{array}{l}\text { Kruskall-Wallis } \\
\text { Test (KW) }\end{array}$ & 5.50 & $1(33)$ & 0.019 \\
\hline $\begin{array}{l}\text { Time to the first phloem ingestion } \\
\text { (E2) phase }\end{array}$ & Mesophyll & - & $4395 \mathrm{~s}$ & $9946 \mathrm{~s}$ & $846 \mathrm{~s}$ & $1880 \mathrm{~s}$ & ANOVA & $\underline{5.32}$ & $1(33)$ & 0.028 \\
\hline $\begin{array}{l}\text { Time to first sustained phloem } \\
\text { ingestion ( }>10 \text { minutes) }\end{array}$ & Mesophyll & - & $8210 \mathrm{~s}$ & $13660 \mathrm{~s}$ & $1345 \mathrm{~s}$ & $1954 \mathrm{~s}$ & KW & 4.29 & $1(33)$ & 0.038 \\
\hline
\end{tabular}




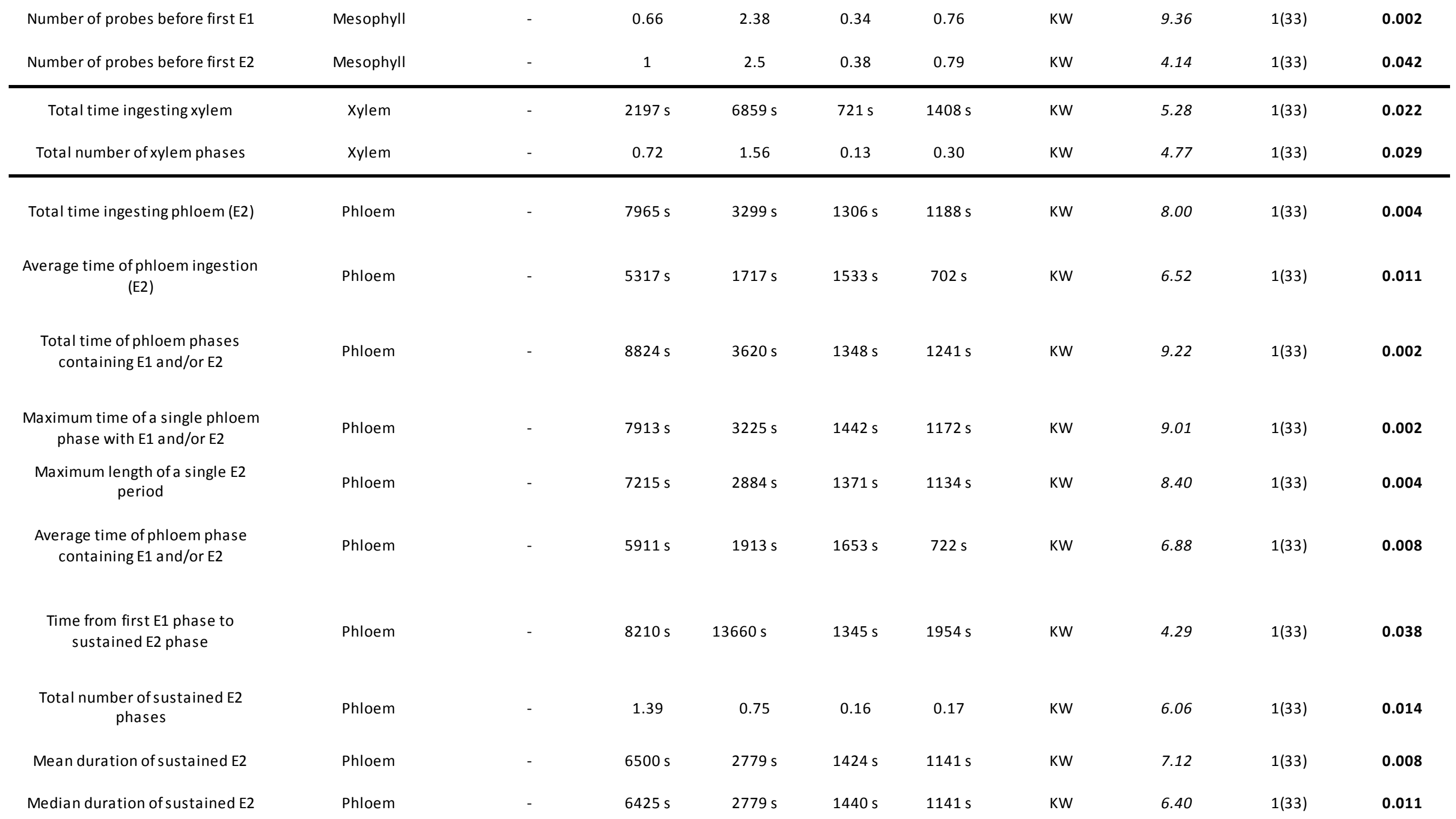


Total time of sustained E2

Phloem

7694

$3060 \mathrm{~s}$

1342

Phloem

3.01

0.67

1.40

$1162 \mathrm{~s}$

KW

W

7.49

7.43

$1(33)$

0.006

Ingestion:Pathway Ratio (\%)

KW

1(33)

0.006 
bioRxiv preprint doi: https://doi org/10.1101/502476; this version posted December 20,2018 . The copyright holder for this preprint (which was not certified by peer review) is the author/funder, who has granted bioRxiv a license to display the preprint in perpetuity. It is made available under aCC-BY-NC-ND 4.0 International license.

Table 3: Statistical results of plant defence gene expression assessed by qPCR showing $\chi^{2}$ and $p$ values (significant values are shown in bold)

\begin{tabular}{|c|c|c|c|c|c|c|c|c|}
\hline \multirow{3}{*}{$\begin{array}{c}\text { Gene } \\
\text { HvTHIO1 }\end{array}$} & \multicolumn{8}{|c|}{ Explanatory variable } \\
\hline & \multicolumn{2}{|c|}{ Plant } & \multicolumn{2}{|c|}{ Aphid infestation } & \multicolumn{2}{|c|}{ Plant $\mathrm{x}$ infestation } & \multicolumn{2}{|c|}{ Experimental Block } \\
\hline & $x^{2}=11.06$ & $p=<0.001$ & $X^{2}=0.57$ & $p=0.450$ & $x^{2}=11.67$ & $p=0.009$ & $X^{2}=1.10$ & $p=0.894$ \\
\hline HVTHIO2 & $x^{2}=13.62$ & $p=<0.001$ & $x^{2}=0.57$ & $p=0.449$ & $x^{2}=14.31$ & $p=0.002$ & $X^{2}=0.47$ & $p=0.976$ \\
\hline HVBTHIO & $x^{2}=14.29$ & $p=<0.001$ & $x^{2}=1.12$ & $p=0.290$ & $x^{2}=16.10$ & $p=0.001$ & $X^{2}=0.15$ & $p=0.997$ \\
\hline$H v A 1$ & $X^{2}=5.77$ & $p=0.016$ & $x^{2}=1.46$ & $p=0.226$ & $x^{2}=4.57$ & $p=0.210$ & $x^{2}=4.58$ & $p=0.206$ \\
\hline$H v N P R 1$ & $x^{2}=1.12$ & $p=0.290$ & $X^{2}=1.85$ & $p=0.174$ & $x^{2}=8.46$ & $p=0.037$ & $x^{2}=3.64$ & $p=0.457$ \\
\hline HvERF1 & $x^{2}=7.00$ & $p=0.008$ & $X^{2}=4.81$ & $p=0.028$ & $X^{2}=12.26$ & $p=0.006$ & $X^{2}=2.24$ & $p=0.691$ \\
\hline HVLOXA & $x^{2}=4.81$ & $p=0.028$ & $X^{2}=4.48$ & $p=0.034$ & $x^{2}=8.05$ & $p=0.045$ & $X^{2}=3.11$ & $p=0.539$ \\
\hline HvLOX2 & $x^{2}=5.49$ & $p=0.019$ & $X^{2}=2.76$ & $p=0.096$ & $x^{2}=8.46$ & $p=0.037$ & $X^{2}=3.97$ & $p=0.410$ \\
\hline$H v J A Z$ & $x^{2}=2.85$ & $p=0.131$ & $X^{2}=0.57$ & $p=0.450$ & $x^{2}=3.55$ & $p=0.315$ & $x^{2}=9.42$ & $p=0.055$ \\
\hline
\end{tabular}


bioRxiv preprint doi: https://doi.org/10.1101/502476; this version posted December 20,2018 . The copyright holder for this preprint (which was not certified by peer review) is the author/funder, who has granted bioRxiv a license to display the preprint in perpetuity. It is made available under aCC-BY-NC-ND 4.0 International license.

Table 4: Dunn's test post-hoc analysis of qPCR results significant for plant $x$ time-point interaction, showing $t$ and $\mathrm{p}$ values for each pairwise comparison; $\mathrm{C}=$ Concerto, $\mathrm{H}=\mathrm{Hsp} 5,0=0 \mathrm{~h}$ infestation, 24 $=24 \mathrm{~h}$ aphid infestation (significant values are shown in bold).

\begin{tabular}{|c|c|c|c|c|c|c|c|c|c|c|c|c|}
\hline \multirow{3}{*}{$\begin{array}{c}\text { Gene } \\
\text { HVTHIO1 }\end{array}$} & \multicolumn{12}{|c|}{ Pairwise comparison } \\
\hline & \multicolumn{2}{|c|}{$\mathrm{CO}: \mathrm{C2} 4$} & \multicolumn{2}{|c|}{$\mathrm{CO}: \mathrm{HO}$} & \multicolumn{2}{|c|}{$\mathrm{CO}: \mathrm{H} 24$} & \multicolumn{2}{|c|}{ C24:HO } & \multicolumn{2}{|c|}{ C24:H24 } & \multicolumn{2}{|c|}{$\mathrm{HO}: \mathrm{H} 24$} \\
\hline & $\begin{array}{c}t= \\
0.69\end{array}$ & $\begin{array}{c}P= \\
0.244\end{array}$ & $\begin{array}{l}t=- \\
2.19\end{array}$ & $\begin{array}{c}P= \\
0.014\end{array}$ & $\begin{array}{l}t=- \\
1.82\end{array}$ & $\begin{array}{c}P= \\
0.034\end{array}$ & $\begin{array}{l}t=- \\
2.89\end{array}$ & $\begin{array}{c}P= \\
0.001\end{array}$ & $\begin{array}{l}t=- \\
2.51\end{array}$ & $\begin{array}{c}P= \\
0.006\end{array}$ & $\begin{array}{c}t= \\
0.37\end{array}$ & $\begin{array}{c}P= \\
0.354\end{array}$ \\
\hline HvTHIO2 & $\begin{array}{c}t= \\
1.28\end{array}$ & $\begin{array}{c}P= \\
0.099\end{array}$ & $\begin{array}{l}t=- \\
1.76\end{array}$ & $\begin{array}{c}P= \\
0.038\end{array}$ & $\begin{array}{l}t=- \\
1.97\end{array}$ & $\begin{array}{c}P= \\
0.024\end{array}$ & $\begin{array}{l}t=- \\
3.05\end{array}$ & $\begin{array}{c}P= \\
0.001\end{array}$ & $\begin{array}{l}t=- \\
3.26\end{array}$ & $\begin{array}{c}P= \\
<0.001\end{array}$ & $\begin{array}{l}t=- \\
0.21\end{array}$ & $\begin{array}{c}P= \\
0.415\end{array}$ \\
\hline HvBTHIO & $\begin{array}{c}t= \\
1.33\end{array}$ & $P=0.09$ & $\begin{array}{l}t=- \\
2.08\end{array}$ & $\begin{array}{c}P= \\
0.018\end{array}$ & $\begin{array}{l}t=- \\
1.92\end{array}$ & $\begin{array}{c}P= \\
0.022\end{array}$ & $\begin{array}{l}t=- \\
3.42\end{array}$ & $\begin{array}{c}P= \\
<0.001\end{array}$ & $\begin{array}{c}t=- \\
3.26\end{array}$ & $\begin{array}{c}P= \\
<0.001\end{array}$ & $\begin{array}{c}t= \\
0.16\end{array}$ & $\begin{array}{c}P= \\
0.436\end{array}$ \\
\hline HVNPR1 & $\begin{array}{c}t= \\
2.62\end{array}$ & $\begin{array}{c}P= \\
0.004\end{array}$ & $\begin{array}{c}t= \\
0.91\end{array}$ & $\begin{array}{c}P= \\
0.182\end{array}$ & $\begin{array}{c}t= \\
0.21\end{array}$ & $\begin{array}{c}P= \\
0.415\end{array}$ & $\begin{array}{l}t=- \\
1.71\end{array}$ & $\begin{array}{c}P= \\
0.043\end{array}$ & $\begin{array}{l}t=- \\
2.41\end{array}$ & $\begin{array}{c}P= \\
0.008\end{array}$ & $\begin{array}{c}t=- \\
0.69\end{array}$ & $\begin{array}{c}P= \\
0.244\end{array}$ \\
\hline HVERF1 & $\begin{array}{c}t= \\
2.03\end{array}$ & $\begin{array}{c}P= \\
0.021\end{array}$ & $\begin{array}{l}t=- \\
1.38\end{array}$ & $\begin{array}{c}P= \\
0.082\end{array}$ & $\begin{array}{l}t=- \\
0.32\end{array}$ & $\begin{array}{c}P= \\
0.374\end{array}$ & $\begin{array}{l}t=- \\
3.42\end{array}$ & $\begin{array}{c}P= \\
<0.001\end{array}$ & $\begin{array}{l}t=- \\
2.35\end{array}$ & $\begin{array}{c}P= \\
<0.001\end{array}$ & $\begin{array}{c}t= \\
1.06\end{array}$ & $\begin{array}{c}P= \\
0.143\end{array}$ \\
\hline HVLOXA & $\begin{array}{c}t= \\
1.12\end{array}$ & $\begin{array}{c}P= \\
0.132\end{array}$ & $\begin{array}{l}t=- \\
1.66\end{array}$ & $\begin{array}{c}P= \\
0.048\end{array}$ & $\begin{array}{c}t= \\
0.21\end{array}$ & $\begin{array}{c}P= \\
0.415\end{array}$ & $\begin{array}{l}t=- \\
2.77\end{array}$ & $\begin{array}{c}P= \\
0.002\end{array}$ & $\begin{array}{l}t=- \\
0.91\end{array}$ & $\begin{array}{c}P= \\
0.182\end{array}$ & $\begin{array}{c}t= \\
1.87\end{array}$ & $\begin{array}{c}P= \\
0.030\end{array}$ \\
\hline$H v L O X 2$ & $\begin{array}{c}t= \\
1.49\end{array}$ & $\begin{array}{c}P= \\
0.067\end{array}$ & $\begin{array}{l}t=- \\
1.33\end{array}$ & $\begin{array}{c}P= \\
0.091\end{array}$ & $\begin{array}{l}t=- \\
0.48\end{array}$ & $\begin{array}{c}P= \\
0.315\end{array}$ & $\begin{array}{l}t=- \\
2.83\end{array}$ & $\begin{array}{c}P= \\
0.002\end{array}$ & $\begin{array}{l}t=- \\
1.97\end{array}$ & $\begin{array}{c}P= \\
0.024\end{array}$ & $\begin{array}{c}t= \\
0.85\end{array}$ & $\begin{array}{c}P= \\
0.196\end{array}$ \\
\hline
\end{tabular}


Table 5: Analysis of deviance table for the scores on each principal component (\% variation explained is indicated in brackets) derived from Principal Component Analysis of phloem amino acid composition (significant values are shown in bold)

\begin{tabular}{ccccccc}
\hline \multirow{2}{*}{ Explanatory Variable } & \multicolumn{2}{c}{$\mathrm{PC1}(34.38 \%)$} & \multicolumn{2}{c}{$\mathrm{PC2}(17.80 \%)$} & \multicolumn{2}{c}{$\mathrm{PC}(10.89 \%)$} \\
& $\mathrm{X}^{2}(\mathrm{df})$ & $\mathrm{p}$-value & $\mathrm{X}^{2}(\mathrm{df})$ & $\mathrm{p}$-value & $\mathrm{X}^{2}(\mathrm{df})$ & $\mathrm{p}$-value \\
\hline Plant & $40.11(1)$ & $<\mathbf{0 . 0 0 1}$ & $5.40(1)$ & $\mathbf{0 . 0 2 0}$ & $11.98(1)$ & $<\mathbf{0 . 0 0 1}$ \\
Aphid infestation & $0.29(1)$ & 0.585 & $0.24(1)$ & 0.626 & $2.26(1)$ & 0.131 \\
Time-point & $5.42(1)$ & $\mathbf{0 . 0 1 9}$ & $3.05(1)$ & 0.080 & $0.08(1)$ & 0.765 \\
Plant x time-point & $0.05(1)$ & 0.816 & $2.17(1)$ & 0.140 & $1.97(1)$ & 0.159 \\
RNA Harvest & $0.17(1)$ & 0.671 & $1.92(1)$ & 0.166 & $0.67(1)$ & 0.413 \\
\hline
\end{tabular}


Table 6: Analysis of deviance table for essential amino acids as a percentage of total amino acids in phloem sap of $\mathrm{Hsp5}$ and Concerto leaves (significant values are shown in bold).

\begin{tabular}{ccc}
\hline Explanatory Variable & \multicolumn{2}{l}{ Essential Amino acid (\%) } \\
& $\mathrm{X}^{2}$ (df) & p-value \\
\hline Plant & $23.35(1)$ & $<0.001$ \\
Aphid infestation & $0.13(1)$ & 0.716 \\
Time-point & $8.82(1)$ & $\mathbf{0 . 0 0 2}$ \\
Plant x time-point & $0.39(1)$ & 0.530 \\
RNA Harvest & $2.01(1)$ & 0.155 \\
\hline
\end{tabular}




\section{Figure Legends}

Fig 1. Aphid performance on a susceptible barley cultivar (Concerto) and partially-resistant wild relative (HsP5). A) Survival of aphid nymphs over seven days. Number of model observations $=216 . \mathrm{C}=$ Concerto; $\mathrm{H} 5=\mathrm{Hsp} 5 ; \mathrm{Rp}=$ R. padi; $\mathrm{Sa}=\mathrm{S}$. avenae; $\mathrm{Uh}=U$. humboldti. B) Nymph mass gain and C) intrinsicrate of population increase ( $\mathrm{rm}$ ) of the three aphid species while feeding from the two plant types. Values represent means \pm SE. Number of model observations $=72$. Letters indicate which groups are similar to each other based on least squares means analysis with Tukey correction.

Fig. 2: Representative examples of feeding patterns derived from EPG waveforms of $R$. padi feeding from susceptible Concerto (A) and partially-resistant Hsp5 (B). Diagrams show the frequency and length of each feeding parameter overa 6h (21600s) period. Feeding patterns are split into the five main waveforms observed: non-probing of plant tissue (np), probing into epidermal and mesophyll tissue (the pathway phase (C), sal iva secretion into phloem (E1), phloem ingestion (E2), and xylem ingestion (G).

Fig 3: EPG parameters indicative of epidermal, mesophyll and mesophyll/phloem resistance factors. A) Time (s) from start of EPG recording to first stylet puncture of leaf tissue. B) Duration (s) of first stylet probe into plant tissue. C) Time (s) since start of EPG recording until stylet puncture of a sieve tube element. D) Time (s) from start of EPG recording until sustained phloem ingestion. $A, B$ and $C$ values represent means \pm SE. Number of model observations $=34$.

Fig 4: EPG parameters indicative of vascular (phloem and xylem) resistance factors. A) Time (s) from first stylet penetration of a sieve tube element to first sustai ned phloem ingestion.

B) Total time (s) of sustained phloem feeding. C) Ratio of time spent in phloem phase relative to the pathway phase; values represent means \pm SE. D) Total time (s) ingesting xylem. Number of model observations $=34$.

Fig. 5: Trichome densities in the two plant types. A) Median non-glandular trichome densities (No. $\mathrm{cm}^{-2}$ ) and confidence intervals for Concerto and Hsp5. B) Polarised light micrograph showing the contrasting leaf hair densities between HsP5 (top) and Concerto (bottom). Number of model observations $=30$. 
Fig 6. Expression patterns of thionin and phytohormone signalling genes $0 \mathrm{~h}$ and $24 \mathrm{~h}$ after aphid infestation. All gene expression values are relative to the mean expression of two reference genes, $H v U B C$ and $H v C Y P$, and normalised to uninfested control plants. Foldchange, 2- $-\Delta \Delta \mathrm{Ct}$, is relative to the expression of $\mathrm{cv}$. Concerto at $0 \mathrm{~h}$. Boxplots show median and confidence intervals; total number of model observations for each gene $=20$.

Fig. 7: Amino acid composition of leaf phloem exudates of Hsp5 and Concerto. A and B) phloem amino acid composition in uninfested leaves of Concerto and $\mathrm{Hsp5}$, respectively, at time zero. C) Biplot of scores on the first two principal components explaining $>50 \%$ of the detected variation in amino acid composition. D) \% proportion of essential and nonessential amino acids in phloem exudates of uninfested Concerto and Hsp5leaves at time zero. 
bioRxiv preprint doi: https://doi.org/10.1101/502476; this version posted December 20, 2018. The copyright holder for this preprint (which was not certified by peer review) is the author/funder, who has granted bioRxiv a license to display the preprint in perpetuity. It is made available under aCC-BY-NC-ND 4.0 International license.

\section{Figures}
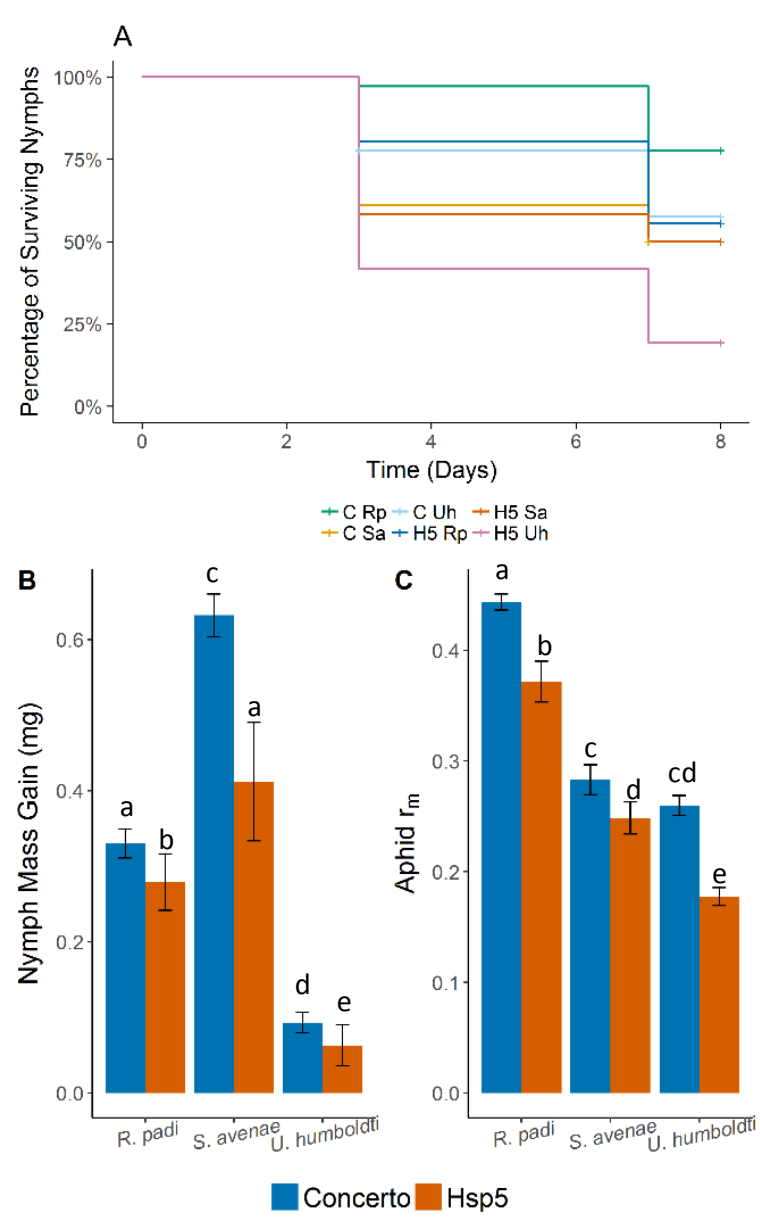

Fig. 1 
bioRxiv preprint doi: https://doi.org/10.1101/502476; this version posted December 20, 2018. The copyright holder for this preprint (which was not certified by peer review) is the author/funder, who has granted bioRxiv a license to display the preprint in perpetuity. It is made available under aCC-BY-NC-ND 4.0 International license.

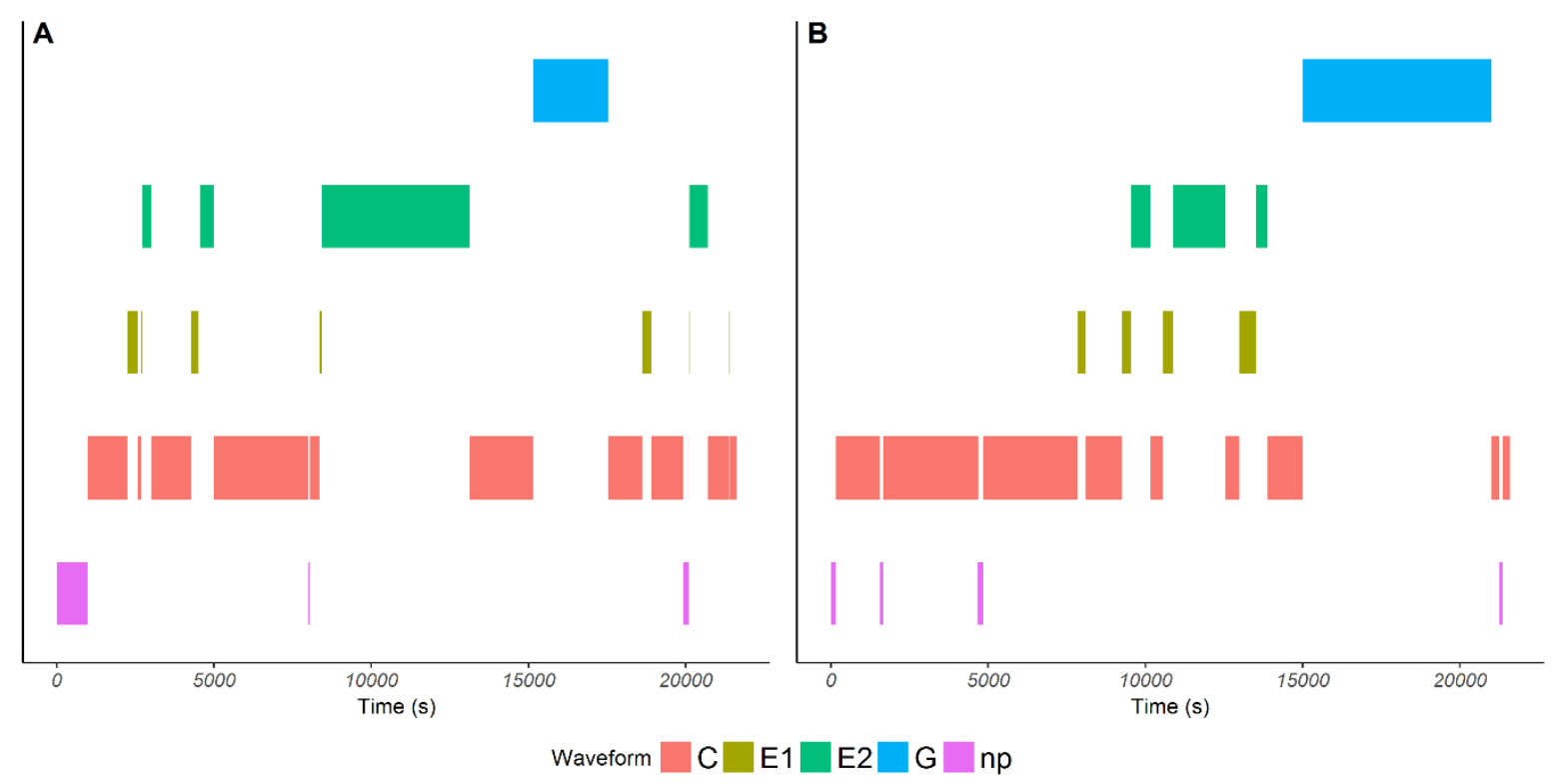

Fig. 2 
bioRxiv preprint doi: https://doi.org/10.1101/502476; this version posted December 20, 2018. The copyright holder for this preprint (which was not certified by peer review) is the author/funder, who has granted bioRxiv a license to display the preprint in perpetuity. It is made available under aCC-BY-NC-ND 4.0 International license.
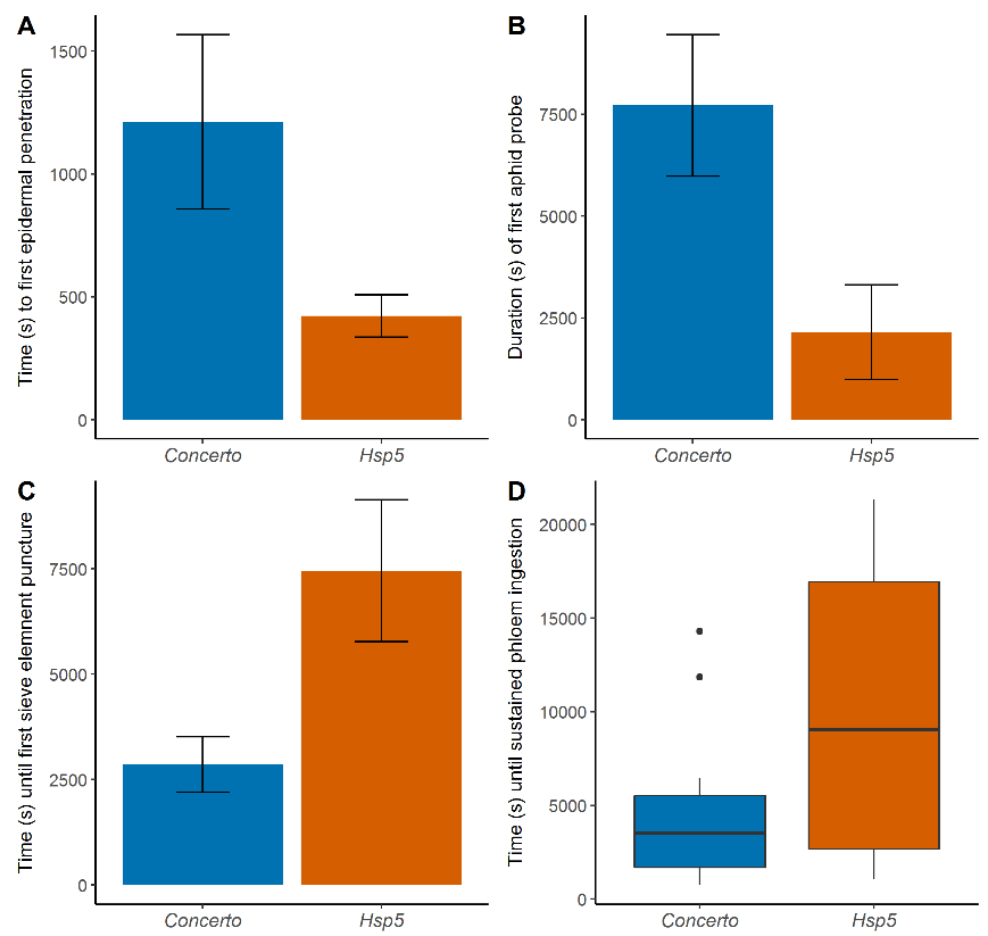

Concerto 1 Hsp5

Fig. 3 
bioRxiv preprint doi: https://doi.org/10.1101/502476; this version posted December 20, 2018. The copyright holder for this preprint (which was not certified by peer review) is the author/funder, who has granted bioRxiv a license to display the preprint in perpetuity. It is made available under aCC-BY-NC-ND 4.0 International license.
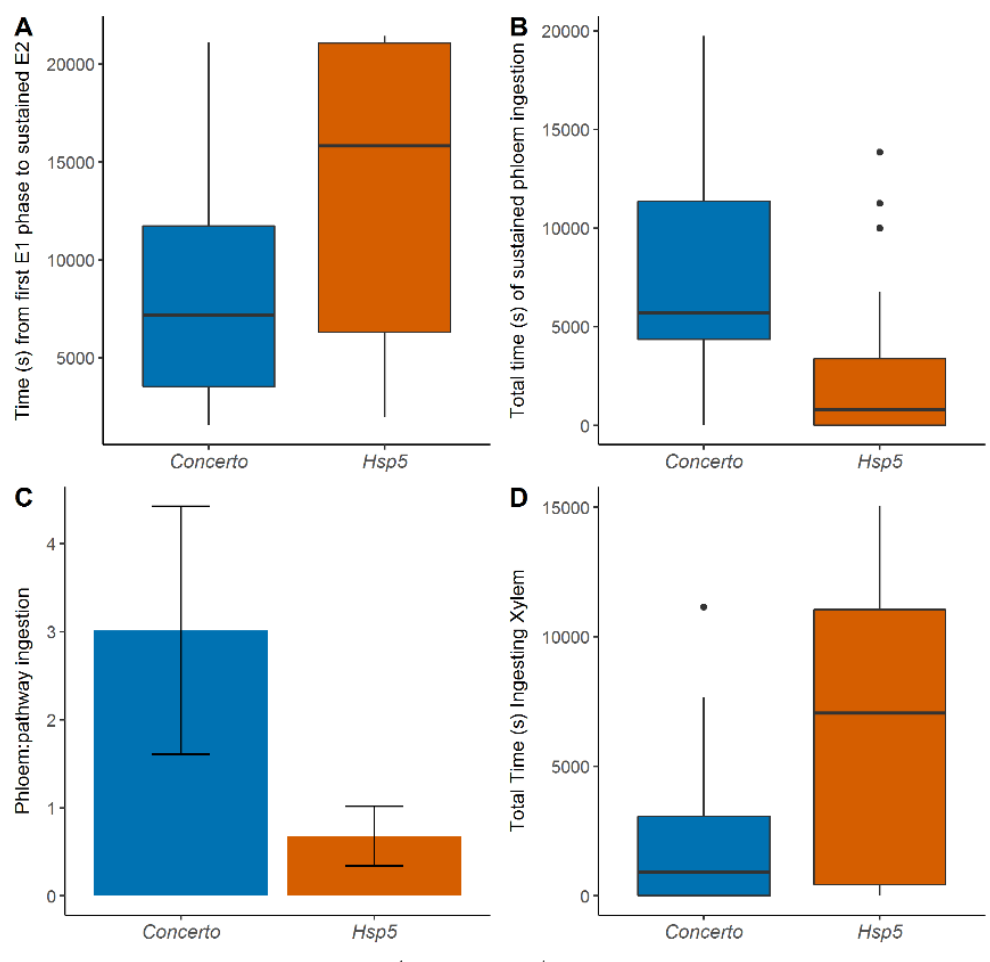

Fig. 4 
bioRxiv preprint doi: https://doi.org/10.1101/502476; this version posted December 20, 2018. The copyright holder for this preprint (which was not certified by peer review) is the author/funder, who has granted bioRxiv a license to display the preprint in perpetuity. It is made available under aCC-BY-NC-ND 4.0 International license.
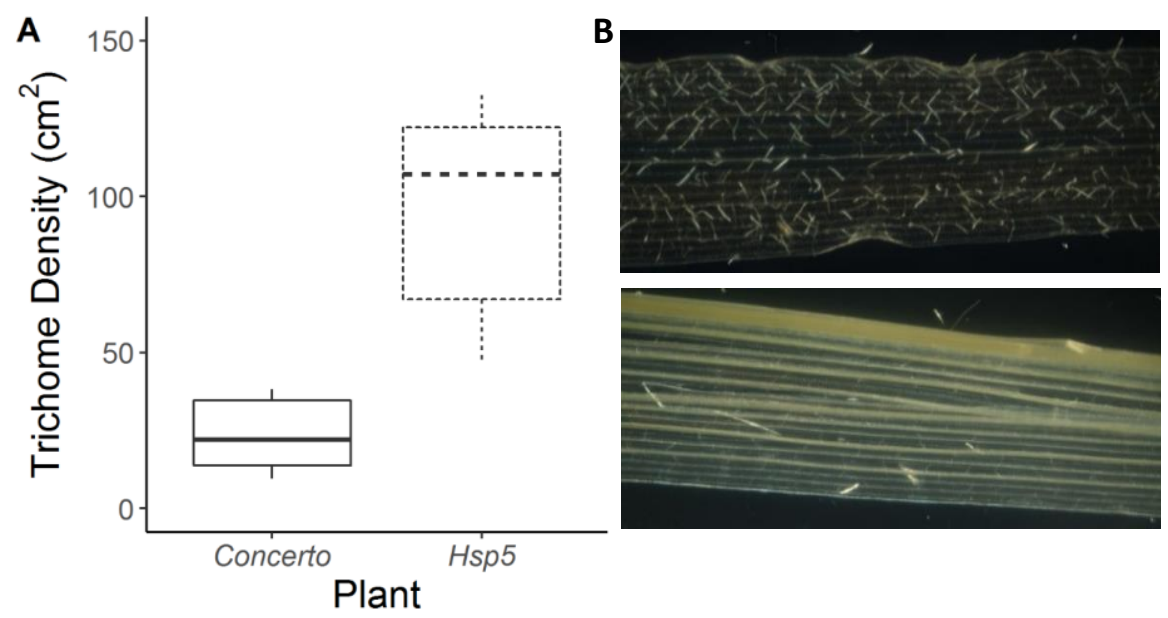

Fig. 5 
bioRxiv preprint doi: https://doi.org/10.1101/502476; this version posted December 20, 2018. The copyright holder for this preprint (which was not certified by peer review) is the author/funder, who has granted bioRxiv a license to display the preprint in perpetuity. It is made available under aCC-BY-NC-ND 4.0 International license.

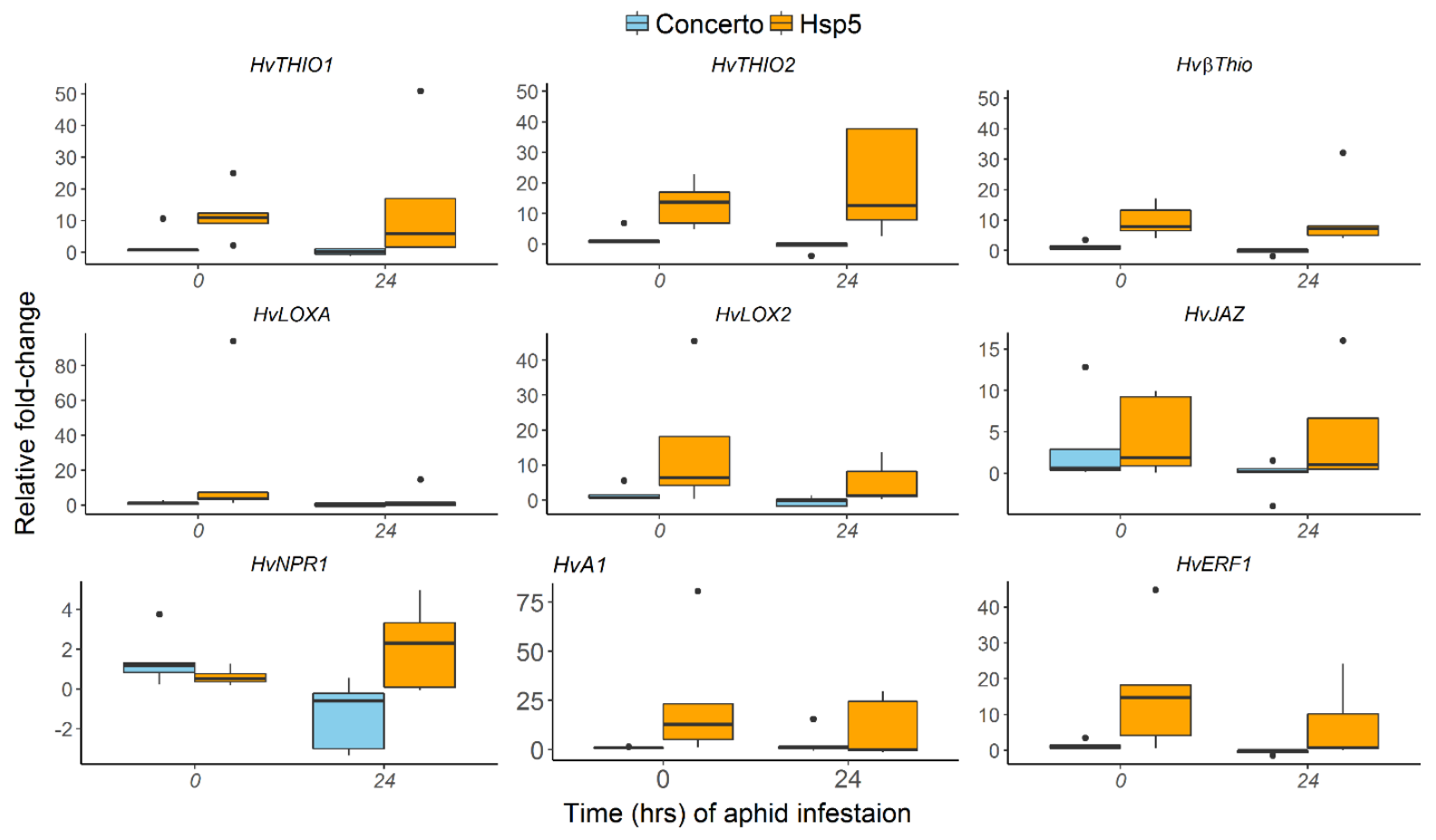

Fig. 6 
bioRxiv preprint doi: https://doi.org/10.1101/502476; this version posted December 20, 2018. The copyright holder for this preprint (which was not certified by peer review) is the author/funder, who has granted bioRxiv a license to display the preprint in perpetuity. It is made available under aCC-BY-NC-ND 4.0 International license.

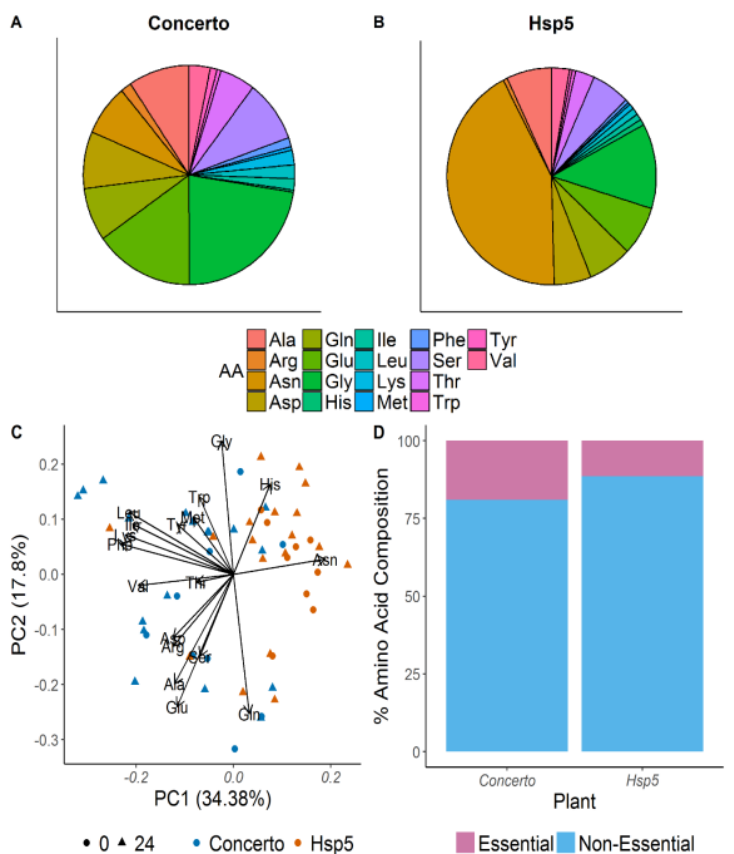

Fig. 7 